\title{
TÜRKIYE GUMHURIYETI'NIN BIR PROPAGANDA VE TANITIM HAMLESI: 1926 SEYYAR SERGI VE AVRUPA SEYAHATI
}

\author{
CELIL BOZKURT*
}

\section{Giriş}

Sergiler, milletlerin maddi ve manevi zenginliklerini tanıttığı ve bunlar üzerinden ticari bir fayda sağladığı önemli teşhir mekanlarıdır. Tarihi oldukça gerilere giden sergilerin uluslararası bir nitelik kazanması 19. yüzyılın ortalarına rastlamaktadır. İngiltere'nin ürettiği malları tanıtmak ve bu bağlamda yeni pazarlar bulmak için 1851'de Londra'da düzenlediği sergi, ilk uluslararası sergi olma özelliği taşımaktadır. Londra Sergisi'ne ABD, Fransa, İspanya, Portekiz, Prusya, Rusya, Flemenk ve Zolverein ülkeleriyle birlikte Osmanlı Devleti de katıldı. ${ }^{1}$ Osmanlı Devleti, devletlerin bir nevi ekonomik ve mali güçlerini de sergilediği uluslararası sergilere mümkün mertebe katılmak azmindeydi. Böylelikle, hem ekonomik gücünü göstermek hem de batılı büyük devletler safinda yerini almak istedi. Nitekim Osmanlı Hükümeti, 1851 Londra Sergisine katılma nedenini "ülke topraklarının verimliliğini göstermek, Osmanlı tebaasının tarım, sanayi ve sanat alanlarındaki kabiliyetini kanıtlamak ve Padişahın ülkenin gelişmesi yolunda sarf ettiği gayreti ortaya koymak" olarak açıklıyordu. ${ }^{2}$

Osmanlı Devleti'nin katıldığı uluslararası sergiler şunlardır:

1851 Londra Uluslararası Sergisi

1855 Paris Uluslararası Sergisi

1862 Londra 2. Uluslararası Sergisi

1863 İstanbul Sergi-i Umumi-i Osmani Uluslararası Sergisi

\footnotetext{
* Doç. Dr., Düzce Üniversitesi, Akçakoca Bey Siyasal Bilgiler Fakültesi, Uluslararası İlişkiler Bölümü, Düzce/TÜRKIYE, celilbozkurt@duzce.edu.tr

Rifat Önsoy, "Osmanlı İmparatorluğu'nun Katıldığ İlk Uluslararası Sergiler ve Sergi-i Umumi-i Osmani (1863 İstanbul Sergisi), Belleten, Gilt 48, Say1 185, Ocak 1983, s. 195.

2 Önsoy, a.g.m., s. 195.
} 
1867 Paris 2. Uluslararası Sergisi

1873 Viyana Uluslararası Sergisi

1889 Paris 3. Uluslararası Sergisi

1892 Chicago Uluslararası Sergisi

1900 Paris 4. Uluslararası Sergisi ${ }^{3}$

Osmanlı Devleti, 1863 yılında İstanbul'da düzenlediği "Sergi-i Umumi-i Osmani" adlı uluslararası sergiyle dünya devletlerine kendi organizasyon ve temsil becerisini göstermek istedi. Serginin amacı, öncekilerden farklı olarak Osmanlı ekonomisinin sorunlarını tespit etmek ve bunlara köklü çözümler aramaktı. Babıali, konuya verdiği önemin bir göstergesi olarak serginin işlerini yürütmek üzere kurulan üst komitenin başına dönemin Maliye Nazırı Prens Mustafa Fazıl Paşa'yı getirdi. Başlangıçta, sergide sadece yerli ürünlerin teşhiri düşünülmüşse de sonradan Avrupa'dan gönderilecek yeni icat makine ve aletlerin de teşhirine karar verildi. Sergide pavyon adıyla oluşturulan 13 bölümde 10 bin kalem teşhir edildi. Sergi-i Umumi-i Osmani, Avrupa'da büyük ilgi uyandırırken, muhtelif ülkelerden çok sayıda basın ve meslek erbabı sergiyi ziyaret için İstanbul'a geldi. Yaklaşık 5 ay açık kalan sergiyi 100-150 bin kişi ziyaret etti. ${ }^{4}$

Osmanlı döneminde uluslararası sergilere katılma hususunda ortaya konulan devlet iradesi, Cumhuriyet döneminde de devam ettirildi. Devletin ilgili kurumları, en az siyasi bağımsızlık kadar önem atfettiği ekonomik bağımsızlığı güçlendirmek ve Türk ekonomisini evrensel boyutlara taşımak için uluslararası sergileri bir firsat olarak değerlendirdi. Lozan Konferansı'nın ara döneminde toplanan İzmir İktisat Kongresi'nde, yeni Türk devletinin ekonomi ilkeleri belirlenirken uluslararası sergilere katılım hususuna da güçlü vurgular yapıldı. Sabık Muhasebe-i Umumiye Müdür-ü Umumisi Raşit Bey, kongrenin hazırlık sürecinde Milli Türk Ticaret Birliğine gönderdiği raporda, Türk emtia ve mamulatının tanıtılması hususunda şu hususları önerdi:

Madde 9: "Cihanın her tarafinda tesis olunacak sergilere iştirak olunması, buralarda eşya teşhir edenlere Hükümetçe nakden muavenet ve ikramiye verilmesi”"

3 Yeşim Duygu Ergüney-Nuran Kara Pilehvarian, "Ondokuzuncu Yüzyll Dünya Fuarlarında Osmanl Temsiliyeti", Megaron, Cilt 10, Sayı 2, 2015, s. 227-239. Ayrıca bkz. Semra Germaner, Osmanl İmparatorluğu'nun Uluslararası Sergilere Katılımı ve Kültürel Sonuçları, Tarih ve Toplum, Cilt 16, Sayı 95, s. 289-296.

4 Önsoy, a.g.m., s. 206-235. 
Madde 10: Türkiye'nin mahsulat ve mamulatını teşhir etmek üzere İstanbul'da saltanat-ı ferdiyenin lağvı hasebiyle boşta kalan saraylardan birinde büyük bir sergi vücuda getirilmesi"s

Yine "İstanbul Vilayeti Esnaf Cemiyetleri Heyet-i Müttehidesi tarafindan yapılan çalışmalar ve temsilcileri tarafindan Kongre'de sunulacak esaslar" kısmının 13. Maddesi'nde "Milli mahsulat, mamulat ve masnuata ait bir meşher-i umumi bir mekteb-i sanayiin küşadı." önerildi. Kongre'nin "Kabul Edilen Esaslar" başlı̆̆ılla tanımlanan "Ticaret-i Hariciye Müesseseleri”" kısmının 5. Maddesi'nde "Ticaret-i hariciyeyi teshil için memleketimizin muayyen mahallerinde ticaret-i hariciye, mahsulat ve mevadd-1 ibtidaiye sergileri tesisi" kararına varıldı. ${ }^{7}$

Türkiye Cumhuriyeti, İzmir İktisat Kongresi’nde alınan kararlara uygun olarak uluslararası sergilere katılım bağlamında önemli adımlar attı. 1925 yılında Lozan, Paris ve Londra'da düzenlenen uluslararası sergilere Vekalet Müsteşarı Vahid Bey, müfettiş olarak görevlendirildi. Aynı yıl Lozan'daki sergiye Ziraat Bankası Umur-u Ziraiye Şubesi Müdürü Daniş Bey müfettiş olarak gönderildi. 1929'da kurulan Milli İktisat ve Tasarruf Cemiyeti, uluslararası sergilere katılım hususunda mesai sarf etti. Macaristan'ın 1931 yılında Ankara'da açılan Ziraat Teknik Sergisine katılmasına karşılık Cumhuriyet hükümeti de aynı sene düzenlenen Budapeşte Sergisi'ne katılmaya karar verdi. ${ }^{8}$

Türkiye'de Uluslararası boyutta bir seyyar sergi oluşturma fikri, İkinci Meşrutiyet Dönemine kadar gitmektedir. İstanbul Ticaret ve Sanayi Odası, 5 Teşrin-i Sani 1325 [18 Kasım 1909] tarihli ruznamesinde, "Emtia ve mahsulatı memlekete hariçte mahreçler tedarikâtını temin ve teshil etmek maksadile vapur dahilinde sabih sergi (seyyar sergi) vücuda getirilerek vapurun Bahrisefit ve Bahrisiyah sahillerindeki mühim limanlara uğratılması mes'elesi"ni değerlendirdi. ${ }^{9}$ Fakat, 1911'de başlayan Trablusgarp Savaşı ve akabinde devam eden Balkan Savaşları, Birinci Dünya Savaşı ve Milli Mücadele, seyyar sergi düşüncesinin hayata geçirilmesini engelledi. Nihayet, 1925'de TBMM'de cereyan eden bütçe

A. Gündüz Ökçün, Türkive İktisat Kongresi 1923 İzmir, Haberler-Belgeler-Yorumlar, Ankara Üniversitesi Siyasal Bilgiler Fakültesi Yayınları, Ankara 1971, s. 108.

6 Ökçün, a.g.e., s. 159.

Ökçün, a.ge.e, s. 420.

8 Tiurkiye Sergicilik ve Fuarclhk Tarihi, (Proje Yöneticisi: Gökhan Akçura, Editör: Günel Tüzün), Tarih Vakfi, İstanbul 2009, s. 102.

9 Hakkı Nezihi, 50 Yillık Oda Hayatı, T.G İstanbul Ticaret ve Sanayi Odası Neşriyatı, İstanbul 1932, s. 214. 
görüşmeleri sırasında seyyar sergi fikri yeniden gündeme geldi. Akabinde genç Türkiye Cumhuriyeti’nin azmi ve kararlılı̆̆ı sonucunda 1926'da hayata geçirildi.

Bu makalede, 1926 yılında Karadeniz Vapuru'nda oluşturulan ve Türk mallarını Avrupa'ya tanıtmak ve burada yeni pazarlar oluşturmak amacıyla hazırlanan Seyyar Sergi'nin yaklaşık üç ay süren Avrupa seyahati ele alınmaktadır. Türkiye Cumhuriyeti'nin çağdaşlaşma bağlamında projelendirdiği ve büyük önem atfettiği Seyyar Sergi hakkında maalesef akademik bir çalışma mevcut değildir. Seyyar Sergi hakkında yazılanlar, bölük pörçük anlatım ve hatıralardan ibarettir. ${ }^{10}$ Seyyar Sergi, 2006'da Garanti Bankası ile Netherlands Culture Fund'ın sponsorluğunda "Karadeniz: Seyr-i Türkiye" başlıklı bir belgeselle NTV kanalından yayımlandı. Yaklaşık 57 dakika süren belgesel, Seyyar Sergi'nin Avrupa macerasını, yerli ve yabancı basından elde edilen bazı fotoğraf, metin ve anılar eşliğinde anlatmaktadır. ${ }^{11}$ Belgesel, Seyyar Sergi’yi Türk kamuoyunun dikkatine sunması bakımından önemlidir. Seyyar Sergi ayrıca, 2017'de Pınar Ayhan'ın cumhuriyetin kuruluş yıllarını ve dönüm noktalarını anlattığı "Orada Duruverseydi Zaman” adlı müzikaline de konu oldu. Değişik şehir ve mekanlarda gösterime giren müzikal, kamuoyunda büyük ilgiyle karşllandı. ${ }^{12}$

Makalenin araştırma safhasında Türk Devlet Arşivleri, TBMM Zabit Cerideleri, dönemin basın yayın organları, özel kurum yayınları ve Karadeniz Vapuru'nu komuta eden kaptanların hatıralarına müracaat edildi. Konu, ulusal boyutta ele alınmış olup, yabancı basındaki boyutuna değinilmedi. Seyyar Sergi’nin yabancı basındaki akisleri, taşıdığı derinlik ve hacim bakımından başka bir makalenin konusu olmalıdır.

\section{Seyyar Sergi'nin Gündeme Gelişi}

Türkiye Cumhuriyeti’nde bir seyyar serginin oluşturulma fikri, 1341 (1925) yılında TBMM'de yapılan bütçe görüşmelerinde gündeme geldi. Görüşmelerde söz alan İstanbul Milletvekili Kazım Karabekir Paşa, 1923 yılında başkan olarak katıldığı İzmir İktisat Kongresi’ne vurgu yaparak kongrede alınan kararların bir layiha halinde İktisat Vekaleti’ne sunulduğunu, özellikle Ticaret Vekaletine ait olan birçok önemli kararın uygulanmadı̆̆ını hatırlattı. Karabekir Paşa, yeniden

10 Seyyar Sergi hakkında yazılmış bazı popüler yayınlar için bkz. Lemi Özgen, "Bir Ulus Kendini Tanıtıyor", Skylife, Aralık 2007, s. 78-86. "Atatürk Böyle Tanıtmıştı", Cumhuriyet, 16 Aralık 2004.

11 "Karadeniz: Seyr-i Türkiye", NTV, 21 Nisan 2006.

12 "Keşke Orada Duruverseydi Zaman", Milliyet, 18 Ekim 2017; "Pınar Ayhan'la Yakın Tarihe Müzikal Yolculuk", Habertürk, 16 Mayıs 2017. 
bir kongre toplamanın külfetinden bahsederek Ticaret Vekaleti'nin layihada belirtilen maddelerin "kabil-i icra ve idari” olanlarını derhal, diğerlerini de tedricen uygulamaya geçirmesini istedi. Ayrıca, sergiler için ayrılan paranın bütçeden çıkarılmasını eleştiren Karabekir Paşa, "Halbuki İktisat Kongresi'nde bizzat göründü ki daimi sergiler, vatan malını göstermek, sevdirmek ve sarfettirmek için pek lazımdır. Yer yer böyle sergiler açanlara para vermeli, teşvik etmeli, daimi surette vatan malını teşhir etmelidir. Onun için bu fasıldaki İktisat Kongrelerine ait para fazladır. Bilakis sergilere muavenet lazımdı»" diyerek sergilerin önemini vurguladı. ${ }^{13}$

Ticaret Vekili Ali Cenani Bey, bakanlığın sergiler hususundaki hassasiyetini belirterek Avrupa'nın muhtelif şehirlerinde açılacak altı sergiye katılım hususunda hazırlıklar yapıldığını vurguladı. Özellikle Londra'da açılacak tütün sergisi, önemli bir tütün üreticisi olan Türkiye için ayrı bir öneme sahipti. Bu hususta, Londra sefareti bilgilendirilerek İstanbul Ticaret Odası ve diğer tüccarın desteğiyle sergide iki pavyon inşasına başlanacaktı. Ali Cenani Bey, Paris’te açılacak bir sanayi tezyiniye sergisi için de hazırlıkların yapıldığını ve burada bir pavyonun inşa edildiğini belirtti. Kütahya çinileri, Gaziantep el işleri, bakırcılık, dökmecilik ve özellikle halıcılık hususunda Türkiye'nin önemli kalemlere sahip olduğunu vurgulayan Ali Cenani Bey, sergiye katılım hususunda Türk tüccarına devlet desteği sağlanacağını kaydetti. Ayrıca, Lozan ve Leipzig'de açılacak iki panayır için de güçlü bir iradenin olduğunu vurgulayan vekil, Ticaret Vekaleti’nden burada bir komiserin görevlendirilerek panayıra katılmak isteyen tüccara kılavuzluk yapılacă̆ını belirtti. ${ }^{14}$

Ali Cenani Bey, hükümetin ülke içinde planladığı ticaret sergisi için bütçeye koyduğu 15 bin liranın gayet yetersiz olduğundan bahisle, böyle bir sergi için 3-4 yüz bin belki de bir milyon liralık bir fona ihtiyaç duyulduğunu vurguladı. Ali Cenani Bey’in buna bir çözüm önerisi olarak sunduğu plan hayli ilgi çekiciydi:

"Bir ticaret sergisini meydana getirmek kolay bir şey değildir. Bunun yerine bir seyyar sergi teşkilini düşündüm. Belki ekser arkadaşlarımızın hatırına gelir. Ruslar, bundan on beş sene evvel bir seyyar sergi tertip etmişlerdi. İstanbul'a ve Akdeniz'in meşhur limanlarına göndermişlerdi. Bir vapur içinde mahsulat ve masnuatı dahiliyeyi birleştirerek içinde tüccarları da ihtiva etmek üzere gelen

13 TBMM Zabut Ceridesi. Devre II, Cilt 16, s. 34-35.

14 TBMM Zabut Ceridesi. Devre II, Cilt 16, s. 35-36. 
bu Rus sergisi İstanbul'da beş, on gün kaldı ve Avrupa'nın limanlarına giderek muhtevi olduğu eşyayı teşhir etti. Bendeniz de düşünüyorum ki Seyrisefain'den bir vapur alalım. Mesela Karadeniz Vapuru'nu düşündüm. Bunun içinde 130 yatak vardır. Tüccarlarımızdan 130 kişiyi alabilir. Ambarlarda elektrik tertibatı yaparak bir meşher haline koyabiliriz. Bütün mahsulatımızı ve masnuatımızı bu vapurda sergi halinde gösterebiliriz" 15

Ali Cenani Bey, seyyar sergi için yaklaşı 80 bin liralık bir masraf öngörmekteydi. Bu ücret, bütçeye dokunulmadan vapurda eşyasını teşhir eden tüccarın kamara ücretlerinden sağlanacaktı. Bakanlık, vapurun yalnızca seyir ve sefer masraflarını karşılayacaktı. Buna ilaveten, Türkiye'nin dünyaca ünlü tütünleri hem natürel hem de kullanıma uygun paketler halinde vapurda satışa sunularak ayrı bir gelir kalemi oluşturulacaktı. Ali Cenani Bey, 100 bin paket satılabileceği ve her paketten alınacak bir frankla birlikte yaklaşık 100 bin franklık bir gelirin sağlanabileceği kanaatindeydi. Bu bağlamda temel masraflar için bütçeye 60 bin liralık bir ödenek konulmasını önermekteydi. Mecliste yapılan oylamada "Ticaret sergi ve meşher ve müzelerine, tütün ve sanayi tezyiniye sergilerine muavenet ve seyyar sergi masrafi" faslının yekunu olarak 89.450 liralık bir ödenek kabul edildi. ${ }^{16}$

Seyyar Sergi, TBMM'de Seyrisefain İdaresi'nin 1926 senesi bütçe görüşmelerinde yeniden gündemine geldi. Antalya Vekili Rasih Bey, Ticaret Vekili Ali Cenani Bey’in Seyrisefain İdaresi'nin vapur sorununu ve buna dair çözümlerini anlattığı konuşmasına binaen seyyar serginin bir süre daha ertelenmesini tavsiye etti. "Kendi hasılatımızı bir vilayetten diğer vilayete naklini temin etmeden sergi vapurunun manasını anlayamadım” diyen Rasih Bey, bu hususta şunları kaydetti: "Efendiler! Eğer sergi vapuru tütüncülüğü neşredecek ise dünyada tütüncülüğümüz çok yüksektir. Fakat reklamı çok yüksek olduğu halde bu sene hiç satılamadı. Çoğu elimizde duruyor. Demek ki reklam işi değildir. Heyet-i celilenizden istirham ederim, bu sergi işi bu sene de kalsın." "17 Rasih Bey’e cevap veren Ali Cenani Bey, seyyar sergi masrafinın geçen sene ayrılan bütçeyle karşılanacă̆ını, dolayısıyla bunun Seyrisefain İdaresi’nden alınmayacağını hatırlatarak serginin planlandığı gibi hareket edeceğini vurgulad. ${ }^{18}$

15 TBMM Zabut Ceridesi. Devre II, Cilt 16, s. 36.

16 TBMM Zabut Ceridesi. Devre II, Cilt 16, s. 37-38.

17 TBMM Zabut Ceridesi. Devre II, Cilt 22, s. 389.

18 Aynı yer. 


\section{Seyyar Sergi'nin Hazırlıkları}

TBMM'de 1925 ve 1926 bütçe görüşmelerinde etraflıca tartışılan "Seyyar Sergi" projesinin Cumhurbaşkanı Mustafa Kemal Paşa tarafindan onaylanmasıyla birlikte serginin hazırlıklarına başlandı. Ticaret Vekili Ali Cenani Bey, yaptı̆̆ı yazılı açıklamada "Topraklarımıza ait mahsulat ve masnuat ve madeniyatı en fazla münasebetde olduğumuz limanlarda teşhir etmek ve müstehlik piyasaların dikkat ve alakasını bu vesile ile de memleketimiz üzerinde toplamak emeliyle bir seyyar sergi tertip edilmiş ve Seyr-ü Sefain İdaresi’nin en büyük ve en mükemmel vapuru bu sergiye tahsis edilmişdir" diyerek Seyyar Sergi projesini ilk kez kamuoyuyla paylaştı. Açılamada Seyyar Sergi için "Türkiye mahsulat ve masnuatı ilk defa olarak bu şekilde teşhir edilecek ve genç cumhuriyetin iktisadi ve zirai faaliyet ve kabiliyetinin bir aks-i sadası halinde Bahr-i Sefid, Bahr-i Muhit Atlası ve Amerika'nın en mühim limanlarında dolaşacakdır" denilmekteydi. ${ }^{19}$

Ticaret Vekaleti, Seyyar Sergi’nin sanat ve sanayi işlerini yürütmek üzere ticaret müsteşarı, ticaret ve Seyr-i Sefain genel müdürlerinden oluşan bir Tertip Heyeti oluşturdu. Diğer resmi kurumlarla işbirliği halinde olacak olan heyet, gerektiğinde bu kurumlardan personel görevlendirebilecekti. ${ }^{20}$ Tertip Heyeti başkanlığına İstanbul Liman İşletmesi Genel Müdürü Raufi Bey getirildi. Raufi Bey, aynı zamanda Ticaret Vekaleti'ni de temsil edecekti. ${ }^{21}$

Ali Cenani Bey, sergide teşhiri düşünülen ürünlerle ilgili ayrıntılı bir açıllama da yaptı. Buna göre, sergilenecek ürünler şöyle tespit edildi: Pamuk, tütün, meyan kökü, bal, zeytin, meyve, yumurta, tiftik, findık, üzüm, incir, gül yağı, ipek, kuru yemiş, susam, afyon, yapă̆ı, palamut, Şam fistığı gibi tarım ürünleri başta olmak üzere maden ve orman ürünleri ile halı, keçe, kendir tohumu, kendir, çini, nakış ve el işleri. Bu ürünlerin yetiştiği bölgelerin harita ve krokileri de hazırlanacaktı. Ürünlerin özellikleri, olgunlaşma safhaları, ihraç miktarı, bunların ticaretini yapan şirketlerin isim ve adresleri, yabancı dillerde bastırılacak broşürler halinde gelen ziyaretçilere dağıtılacaktı. Sergiye katılmak isteyen şirket ve tüccar için, "uygun şartlarda" vapurda ürün teşhir stantları oluşturulacaktı. ${ }^{22}$ 884.

19 "Seyyar Türk Sergisi", Istanbul Ticaret ve Sanayi Odası Mecmuase (ITSOM), Sayı 5, Mayıs 1341/1925, s.

\footnotetext{
20 Aynı yer.

21 "Rufi Bey", Vakit, 14 Mart 1926.

22 Ayn1 yer.
} 
Maarif, Ziraat ve Nafia Vekaletleri, gerekli gördükleri ürünlerin saptanması ve bunların takibinde Ticaret Vekaleti’yle işbirliği yapacaktı. Ayrıca, Ali Cenani Beyin söz konusu tebliğini vilayetlere ulaştırılmasını sağlayacaktı. Seyyar Sergi'nin 1925 Temmuzunda hareket etmesi kararlaştırıldı. Bundan dolayı 30 Haziran 1925 tarihine kadar sergi hazırlıklarının bitirilmesi istenmekteydi. ${ }^{23}$

Ticaretin Vekaleti’nin açıkladığı Seyyar Sergi projesi, Türk ve Dünya kamuoyunda büyük yankılar uyandırdı. Türk ürünlerini birinci elden almak isteyen muhtelif şirketler, geminin kendi limanlarına uğramasını talep etti. Finlandiya, bu hususta Türk hükümetine resmen başvuru yaparken, ABD elçiliği de geminin Newyork'a uğramasını rica etti. ${ }^{24}$

Ticaret Vekaleti, Seyyar Sergi’yi hazırlama sorumluluğunu başlangıçta Seyr-i Sefain idaresine vermişti. Fakat, sonradan bu işle İstanbul Ticaret ve Sanayi Odası (ITSO) görevlendirildi. İTSO, hazırlık sürecinin Avrupa ayarında bir sergi için yetersiz olduğu kanaatindeydi. Nitekim İTSO, 27 Mayıs 1341/1925 tarihli 20. İçtimasında, Seyyar Sergi işinde acele edilmemesi ve sergi hazırlıklarının daha geniş bir zamanda yapılması gerektiği yönünde bir tavsiye kararı aldı. Bu husustaki resmi açılama şöyleydi:

“...Oda heyeti, keyfiyeti müzakere ederek milli ve beynelmilel sergiler ve bilhassa tasavvur edilen seyyar serginin kısa bir müddet zarfinda memleketin bilumum şu'bat ve meslek ve faaliyet-i iktisadiyesini temsil edecek bir tarzda muvaffakiyetle ikmal ve ihzarı gayr-i mümkün olduğu ve bilumum memalik-i ecnebiyede mevcud ve ma'ruf olan sergiler için bir kaç sene evvel karar verilerek ihzarında bulunulduğu ve ancak bu suretle sergilerden beklenen faidelerin elde edileceği nazar-ı dikkate alınarak bu maksadın daha mükemmel ve muvaffakiyetli bir suretde temin olunabilmesi için hiç olmazsa bir sene müddet tahsis olunarak vapurun gelecek senenin yazında sevk edilmesi ve bu müddet zarfinda bir taraftan vekalet ve ticaret sanayi idarelerinin, diğer taraftan odaların mezkur seyyar sergide teşhir edilecek masnuat ve mamulatın sipariş ve ihzarıyla şimdiden meşgul olmağa başlaması ve bu maksad için vekaletce serginin ehemmiyetiyle mütenasib bir tahsisatın vaz'ı hususunun cevaben Ticaret Vekalet-i Celilesine iş'arının bir vazife-i iktisadiye olduğuna karar verilmişdir." 25

3 Aynı yer.

24 "Seyyar Türk Sergisi Hakkında Anadolu Ajansı'nın Haberi", ITSOM, Sayı 5, Mayıs 1341/1925, s. 885.

25 "Karadeniz Vapuru Sergisi", ITSOM, Say1 6, Haziran 1341/1925, s. 966-967. 
Seyyar Sergi'ye ev sahipliği yapacak gemiler arasında Gül Cemal ve SS [steam ship, buharlı gemi] Karadeniz vapurları öne çıkmaktaydı. Nihayet, Seyr-i Sefain İdaresi'nin en büyük gemilerinden Karadeniz Vapuru'nun ${ }^{26}$ sergi formatına daha uygun olduğuna karar verildi. ${ }^{27}$ Karadeniz, 1 Nisan 1926 tarihinde bakım ve onarım için Haliç Tersanesi'ne çekildi. Geminin inşaat ihalesi 9500 liraya Mimar Muammer Asım Beye verildi. Gemiye ilk olarak dışarıyla bağlantısını kuracak bir balkon tertibatı eklendi. Ayrıca, ürünlerin teşhiri ve satışına yönelik iki bölüm ile bunlara bağlı reyonlar oluşturuldu. Gemideki tüccarın ve şirket temsilcilerinin ticari işlerini yürütmek üzere Ziraat ve İş Bankası'na ait yerler tanzim edildi. Fakat, sonradan sadece İş Bankası şubesinin kurulmasına karar verildi. Gemide bir elektrik tesisatı döşendi, bir firın ve buz imali için Seyr-i Sefain İdaresi’ne başvuruldu. Ayrıca, "Beyoğlu 980" koduyla gemiye bir telefon ilave edildi. Geminin dekorasyonu, Türk tarzı oryantal bir mimariye göre oluşturuldu. ${ }^{28}$ Bazı basın organlarında Seyyar Sergi’ye Almanya'dan uzman getirileceği yönünde çıkan haberler Sergi Tertip Heyeti tarafindan yalanlandı ve serginin tamamen "Türk mesai ve kabiliyetinin bir ürünü” olduğu vurgulandı. ${ }^{29}$

Seyyar Sergi, sadece ekonomik değil ülke tanıtımına yönelik kültürel bir misyon da üstlendi. Bu hususta kamu ve özel kurumlar arasında bir koordinasyon sağlanarak Türkiye Cumhuriyeti’nin muhtelif yönlerine dair kitap ve broşürler hazırlandı. Tertip Heyeti Başkanı Raufi Bey, bizzat ülkeye ait anayasa, zirai gelişme, bankacılık, kooperatifçilik, sigortacılık şirketleri, maden kömürleri, limanlar, iktisadi teşekküller vs. hususlara dair bir kitap hazırladı. ${ }^{30}$ Ayrıca, serginin "Türkiye Neşriyatı" reyonunda sergilenmek üzere Maarif Nezareti tarafindan Matbaa-i Amire Müdüriyeti’nden alınan 87 adet kitap sergi komisyonuna verildi. ${ }^{31}$

26 Karadeniz, Hollanda yapımı bir gemi olarak Wilis adıla 1905'te denize indirildi. 4731 grostonluk geminin boyu $130 \mathrm{~m}$, eni $15.51 \mathrm{~m}$ ve derinliği de $9.07 \mathrm{~m}$ idi. 3500 beygir gücündeki buharl gemi, günde 72 ton kömür yakarak çalışmaktaydı. Geminin ilk sahipleri Rotterdamsche Lloyd, Hollanda'nın Malezya ve Endonezya'daki sömürgelerine ylllarca seferler düzenledi. Gemi, 1924 yılında 4200 İngiliz poundu karşılığında Hollanda'dan alınarak "Karadeniz" adıyla Türkiye Cumhuriyeti'nin ticaret filosuna katıldı. 1926'da Seyyar Sergi gemisi olarak ünlenen Karadeniz, bir süre İstanbul-Batum seferlerinde kullanıldı. Yaklaşık 19 yıllık bir hizmetten sonra hurda niyetiyle İtalyanlara satıldı. Bkz. Oktay Sönmez, Anılarda Gemiler Ufkun Ötesinde Kayboldular, Türkiye İş Bankası Kültür Yayınları, İstanbul 2001, s. 51-58) Ayrıca bkz. Eser Tutel, Seyr-i Sefain Öncesi ve Sonrası, İletişim Yayınları, 3. Baskı, İstanbul 2006, s. 178. Karadeniz Vapuru için bkz. Ek 1.

27 Eser Tutel, Gemiler, Süvariler, İskeleler, İletişim Yayınları, İstanbul 1998, s. 31.

28 "Seyyar Sergide", Vakit, 7 Nisan 1926. Ayrica bkz. Süreyya Gürsu, 1926 Senesinde Yapılan Seyyar Sergi Seferi Hatralan, (Derleyen: Refik Akdoğan), İstanbul 2006, s. 18.

29 "Seyyar Sergi heyet-i tertibiyesi riyasetinden", Vakit, 8 Nisan 1926.

30 "Seyyar Sergide", Vakit, 7 Nisan 1926.

31 Başbakanlık Cumhuriyet Arşivi, 180.09.52.262.1.92. 
TBMM'de 1925 yll bütçe görüşmelerinde "Ticaret sergi ve meşher ve müzelerine, tütün ve sanayi tezyiniye sergilerine muavenet ve seyyar sergi masrafi" faslının yekunu olarak 89.450 liralık bir tahsisatın ayrılmıştı. ${ }^{32} 1926$ yılı bütçe görüşmelerinde Seyyar Sergi'nin "vapur bedeli icarı” olarak 100 bin liralık daha tahsisat ayrıldı. ${ }^{33}$ Sonradan 20 bin liralık ek bir tahsisatın daha ayrılmasına karar verildi. ${ }^{34}$ Bir gazete haberinden Ticaret Vekaletine 30 bin liralık başka bir kaynağın daha aktarıldığı anlaşılmaktadır. ${ }^{35}$

\section{Seyyar Sergi Talimatnamesi ve Sergilenen Ürünler}

1925 yılında "Ticaret Vekaletince Tertip Edilen Seyyar Sergi 1341 [1925]" adıyla üçe katlanır, altı sayfalık bir karton broşür hazırlanarak kamuoyuna dağıtıldı. Broşür, bir çağrı pusulası olmakla birlikte aynı zamanda bir yönerge hükmündeydi. Broşürde, sergiye katılacakların uyması gereken 25 maddelik kurallar, sergilenecek eşyalar ve sergi gemisinin uğrayacağı limanlar belirtilmekteydi. Broşürün ön yüzünde, Seyr-i Sefain İdaresi'nin logosu içinde Karadeniz Vapurunun resmi ile arka yüzünde de güneş kursu içinde Mustafa Kemal Paşa'nın fotoğrafi bulunmaktaydı. ${ }^{36}$

Tertip Heyeti, Istanbul Ticaret ve Sanayi Odası Mecmuasi'nın 1926 yılının Haziran sayısında "Karadeniz Vapuru Sergi ve Seyahat Talimatnamesi" adıyla yeni bir talimatname yayımlandı. Talimatname, sergiye iştirak koşullarını taşıyan 24 madde ile sergilenmesi planlanan 9 kalem eşyanın listesinden oluşuyordu. Talimatnamede, Karadeniz Vapuru'nun kesin hareket gününün gazetelerde ilan edileceği belirtilmekle beraber, vapurun şimdilik Temmuz sonunda İstanbul'dan Avrupa limanlarına açılacağı vurgulanıyordu. Buna karşın mecmuanın düştüğü bir dipnotta, vapurun Nisan sonlarına doğru hareket etmesinin kararlaştırıldığına dikkat çekiliyordu. Talimatname, sonradan yayımlanan "Seyyar Sergi Talimat ve Programı"na göre oldukça kısa olup vapurun uğraması planlanan limanları zikretmiyordu. ${ }^{37}$

Aynı yılda yayımlanan "Seyyar Sergi Talimat ve Programı", bahsi geçen talimatnameye göre oldukça kapsamlıydı. 20 sayfalık bir kitapçıktan oluşan

32 TBMM Zabut Ceridesi. Devre II, Cilt 16, s. 37-38.

3 Resmi Gazete. Sayı 324. Tarih 17.3.1926. s. 1193-1197. Ayrıca bkz. TBMM Zabut Ceridesi. Devre II, Cilt 22, s. 385.

34 TBMM Zabut Ceridesi. Devre II, Gilt 17, s. 326-27.

35 "Seyyar Sergi", Vakit, 8 Haziran 1926.

36 Yılmaz Akkılıç, "Seyyar Sergi", Bursa Defteri, Sayı 24, Aralık 2004, s. 113-116.

37 "Seyyar Türk Sergisi", ITSOM, Sayı 6, Haziran 1341/1925, s. 934-936. 
yeni talimatname, 22 madde ile bu maddelere açıklık getiren 4 ilave maddeden oluşuyordu. Talimatname; vapurun uğrayacağı limanlar, sergiye iştirak, ürünlerin gemiye nakli ve satışı, tüccarın seyahati ve teşhir edilecek mallara kadar belirlenmiş kural ve prensipleri ayrıntılı olarak açıklıyordu. Ayrıca, vapurda şubesi bulunan İş̧ Bankası'nın sergi süresince icra edeceği görevleri 4 madde halinde açıklıyordu. Sergide teşhir edilecek ürünler ise, 2 kısım ve 24 kalem halinde listelenmişti. Kitapçı̆̆ın ilk ön kapağında, Seyr-i Sefain logosu içinde İstanbul'dan kalkan Karadeniz Vapuru'nun önünde yürüyen haber tanrıçası Hermes’in resmedildiği sergi logosu bulunmaktayd. ${ }^{38}$

Seyyar Sergi Talimat ve Programına göre, sergi vapurunun Mayıs sonlarında Avrupa'ya hareket edeceği ve kesinleşmiş hareket tarihinin gazetelerde ilan edileceği belirtiliyordu. Programa göre, Seyyar Sergi’nin uğrayacağı limanlar ve burada kalacağı gün sayısı şöyleydi:

1. Barselona 2

2. Liverpul 3

3. Havr 3

4. Londra 4

5. Hamburg 4

6. Stokholm [Stockholm] 3

7.Helsingfors [Helsinki] 2

8. Leningrad 2

9. Danzig 2

10.Kopenhag 2

11. Amsterdam 2

12. Anvers 2

13. Marsilya 3

14. Cenova 2

15. Napoli 2

38 Seyyar Sergi Talimat ve Program, Hilal Matbaası, 1926. Seyyar Sergi'nin logosu için bkz. Ek 2. 
16. Venedik 2

17. Triyeste [Trieste] 3

18. Batum 2

19. Odesa 2

20. Köstence 2

\section{Varna $3^{39}$}

Türkiye'de bulunan fabrika ve imalathane sahipleri, tüccar, zürra [çiftçiler] ve esnaf, bizzat veya vekilleri aracılığıyla Seyyar Sergiye katılabilecekti. Sergideki malların satışı ve uygulanacak tarifeler, ayrıntılı bir şekilde açıklanmıştı. Sergiye katılan tüccara mallarının miktarına göre muhtelif kolaylıklar sağlanmıştı. Sergiye 3 bin liralık ve üzerinde mal koyan tüccardan yatak ücreti alınmayacaktı. 2 bin liralık eşyası olan tüccara seyahat ücreti üzerinden $\% 50$ ve bin liralık eşyası olan tüccara da \% 20'lik ıskonto yapılacaktı. Sergiye 5 bin liralık eşya tevdi eden tüccar, iaşesini karşılamak şartıyla eğer isterse yanına bir memur alabilecekti. Sergide satılan eşyanın gümrük vergisi, limanın bağlı bulunduğu ülkenin gümrük tarifesine göre müşteriye ait olacaktı. Sergi, seyir halindeyken gemi sofrasından yemek yemek yolculara mecburi tutulmuştu. Ancak, geminin limanda olduğu zamanlarda yemek yemek isteğe bağlıydı. ${ }^{40}$

Tertip Heyeti; teşhir olunan eşyanın çeşidi, cinsi, üretimi ve üretim yeri, sahiplerinin isim ve adreslerini içeren zarif broşüler hazırlayacak, bunları muhtelif lisanlara tercüme ederek geminin uğradığı limanlarda dağıtacaktı. İlan vermek isteyen tüccar, komisyonun uygun gördüğü tarife üzerinden eşya kataloglarına ilan verebilecekti. Sergide satıcı veya yolcu statüsünde bulunanların gemi nizamatına ve komisyon kurallarına uyma mecburiyeti vardı. Tertip Heyeti'nin emrinde Avrupa lisanlarına vakıf tercümanlar bulundurulacak ve bunlar tüccarla müşteri arasındaki iletişimi sağlayacaktı. Ayrıca Tertip Heyeti, teşhir edilen mallarla ilgili limanlarda ziyaretçilere ayrıntılı bilgi verecekti. ${ }^{41}$

Gemide Riyaset-i Cumhur Orkestrası, büfe ve sinema bulunacaktı. İsteyen tüccar, kendi üretimlerine reklam filmi yaptırabilecekti. Yabancı ülkelerde verilecek ziyafetlere katılmak isteyen tüccar, bu tür organizasyonlarda giyilmesi

39 Seyyar Sergi Talimat ve Program, Madde 2, s. 2.

40 Seyyar Sergi Talimat ve Program, Madde 3, 4-12, 13, 14, 19, s. 3-8.

41 Seyyar Sergi Talimat ve Programı, Madde 15, 16, 17, 18, s. 7-8. 
gereken elbise ve şapkaları giymek zorundaydı. Seyahat süresi 3 ay olarak tespit edilmişti. ${ }^{42}$ Seyyar Sergi Talimat ve Programı, ilk 22 maddeye 3 maddelik bir ilave yaparak bazı hususlara açıklık getirmişti. ${ }^{43}$

Seyyar Sergi gemisinde bir şubesi bulunan İş Bankası'nın ${ }^{44}$ görevi, şöyle açıklanmıştı:

1. Sergide hazır bulunmayan malların vekaleten satılması,

2. Sergiden İstanbul, Ankara, İzmir ve Bursa üzerinden çek ödemek ve Türkiye'nin her şehrine havale kabul etmek,

3. İstanbul'dan hareket etmeden Seyyar Sergi şubesinde cari hesap açtırmak ve yolcuların seyahat sürecinde hesabını açık tutmak,

4. İmkan nispetinde para değişimi yapmak,

İş Bankası’nın tüccarla yürüteceği işlemler ve taşıdıkları yükümlülükler ayrıntılı olarak açıklanmıştı. Talimatnamenin son kısmı Seyyar Sergi'de sergilenecek mallara ayrılmıştı. Buna göre, teşhir edilecek mallar, iki kısım halinde düzenlenmişti. Şöyle ki;

\section{A. Birinci Kısım}

Mevad-1 İbtidaiye [Ham maddeler]

\section{Madeniyat [madenler] ve Ahcar-1 Madeniye [madeni taşlar]}

Madenler, taşlar.

\section{Orman}

Tahtalar.

\section{Mevad-1 nesciye [dokuma/tekstil]}

Pamuk, yün tiftik, ipek ve saire.

\section{Hayvani mahsulat (mevad-1 nesciyeden maada)}

Yumurta, balıklar, havyar ve saire.

Seyyar Sergi Talimat ve Program, Madde 20, 21, 22, s. 9.

Seyyar Sergi Talimat ve Programı, Madde 1-3, s. 9-11.

${ }^{4}$ Türkiye IŞS Bankası Tarihi, (Proje yöneticisi: Uygur Kocabaşoğlu), Türkiye İş Bankası Kültür Yayınları, İstanbul 2001, s. 106. 
Nebati [bitkisel] mahsulat

Hububat, meyveler, kuru ve konserve sebzeler, pirinç ve saire.

Attariye

Devaiye, baharat ve boyalar.

B. İkinci Kısım

Madeni mamulat, altın, gümüş, cevahir [değerli taşlar] ve kuyumcu eşyaları

Demir, pirinç, tunç ve bakır eşya.

Alat [aletler/araç gereçler], makine, nakil araçları ve arabalar

Elektrik makineleri ve edevatı, alat-ı ziraiye [tarım araçları], alat-ı sınaiye [sanayi araçları], tenvirat [aydınlatma] ve teshinat [1sıtma] eşyası.

Taş, toprak ve cam mamulat

Porselen ve aynalar.

Haşebi [kereste] mamulat

Mobilya kamışı ve sepet işleri, ev ve matbaa eşyası.

\section{Deri mamulatı}

Ayakkabılar, saraç işleri ve vesaire.

\section{Mensucat}

Mensucat, işlemeli ve örmeli halılar ve saire.

\section{Melbusat [elbise] ve spor}

Erkek ve kadın eşyalarına ait eşya,

şemsiye, baston,

spor eşyası ve saire.

\section{Kağıt ve mukavva mamulat}

\section{Me'kulat [yiyecek] ve meşrubat}

Hayvani me'kulat, bitkisel me'kulat, meşrubat, tatl, şeker ve reçeller. 


\section{Mamulat-1 kimyeviye [kimyasal ürünler]}

Ecza, 1triyat, sabun, mum ve saire.

\section{Tütün, tömbeki [tütün çeşidi] ve sigara}

\section{Her nevi inşaat malzemesi}

Tesisat-1 sihhiye.

\section{Hastaneler ve sıhhi eşya}

Sıhhi eşya, dişçilik ve sair aletler.

\section{Sanayi-i nefise [güzel sanatlar], resim, tablo, nakış ve tezyinat [süsleme]}

Resim, mimari, heykeltıraş, hat ve çini.

\section{Musiki}

Musiki aletleri,

musiki eserleri ve notalar.

\section{Sanat eşyası}

Sanat eşyası, icadlar ve oyuncaklar. ${ }^{45}$

Tertip Heyeti, başlangıçta kurt, tilki, sansar ve kuş gibi Anadolu'dan getirilecek vahşi hayvanları sergide teşhir etmeyi planlamıştı. Bu hayvanlar, vapurun uygun yerlerinde yapılacak ambarlarda kafes içinde teşhir edilecekti. Hatta, tilki celbi dahi yapılmıştı. ${ }^{46}$ Fakat, bunu mahsurlu bulan uzmanların uyarılarının ardından bundan vazgeçildi. ${ }^{47}$

\section{Mustafa Kemal Paşa'nın Seyyar Sergi'yi Teftişi}

Tertip Heyeti, 10 Haziran 1926 tarihinde Seyyar Sergi hakkında 4 maddelik son bir duyuru yayımladi. Duyuruda, Karadeniz Vapuru'nda 11 Haziran Cuma akşamı bir resm-i kabul icra edileceği ve geminin 12 Haziran cumartesi gecesi Gazi Paşa'ya "arz-1 tazimat" etmek üzere Mudanya'ya gideceği bilgisi verildi. Ayrıca,

Seyyar Sergi Talimat ve Program, s. 17-20.

"Seyyar Sergi", Vakit, 13 Mart 1926.

${ }^{47}$ Ziraat Müzesi Müdürü Nihad Bey'in bu husustaki uyarısı için bkz. "Seyyar Sergide hayvanat-1 vahşiye teşhir edilemez", Vakit, 17 Mart 1926. 
seyahate katılacak tüccar ve bilumum mağaza sahiplerinin gemiye yüklenecek malların ikmal ederek gerekli formaliteleri bitirmeleri ve gece merasimine katılacakların teşrifata uygun giyinmeleri rica edildi. ${ }^{48}$

Bu arada Ticaret Vekili Rahmi Bey, Mudanya'da Mustafa Kemal Paşa'nın beğenisine hazırlanan Seyyar Sergi'yi teftiş etmek üzere 11 Haziran'da İstanbul'a geldi. Seyr-i Sefain Genel Müdürü Sadullah Bey, Tertip Heyeti Başkanı Raufi Bey, Gaziantep mebusu Remzi Bey, İstanbul Muhaberat Müdürü Muhsin Bey, Müderris Zühdü Bey ve Riyaset-i Cumhur Orkestrası Şefi Zeki Bey, kendisine refakat etti. ${ }^{49}$

Türk kamuoyunun Seyyar Sergi'ye ilgisi büyük olmakla birlikte iş çevrelerinin sergiye ilgisi beklenenin altında kaldı. Bu hususta Seyr-i Sefain Genel Müdürü Sadullah Bey ile Ticaret Müdürü Muhsin Bey, sergi mahallinde basina açıklamada bulundu. Sadullah Bey, "Hiç olmazsa sergiye tüccar için iş gördükleri mahallere mesela Marsilya’ya, Hamburg'a kadar iştirak etmek imkanı vardı.” sözleriyle duyduğu hayal kırıklığını dile getirdi. Muhsin Bey de "Bizde ticarethaneler behemehal sahipleri başlarında bulundukça muntazam işleyebiliyorlar. Sahipleri bir hafta on gün için bile ayrrlsalar derhal işleri bozuluyor. Ticarethanelerin sahiplerinin ümid edildiği kadar seyyar sergiye iştirak edememelerinin sebeplerinden biri de budur" diyerek tüccarın özgüven ve tecrübe eksikliğine dikkat çekti. ${ }^{50}$

Seyyar Sergi'yi hamil Karadeniz Vapuru'nda 11 Haziran 1926 tarihinde sergi anısına bir balo tertip edildi. Baloya Ticaret Vekili Rahmi ve Maarif Vekili Necati Beyler ile Kolordu Komutanı Şükrü Naili Paşa, İtalya ve Belçika elçileri, Amerikan temsilcisi Amiral Bristol, Fransız Elçiliği çalışanları, Mübadele Komisyonu reisi ve İstanbul basın temsilcileri katıldı. 250 kişinin davet edildiği balo, gece geç vakitlere kadar devam etti. ${ }^{51}$

Karadeniz Vapuru, 12 Haziran'da İstanbul'dan ayrılarak Mudanya Limanı'na hareket etti. Bu sırada Bursa gezisinde bulunan Cumhurbaşkanı Gazi Mustafa Kemal Paşa, beraberinde Ordu Müfettişi Ali Said ve Kolordu Kumandanı Ali Hikmet Paşalar ile Bursa valisi, belediye başkanı ve bazı hükümet memurları olduğu halde Mudanya'ya geldi. Mudanyalıların coşkun tezahüratıyla karşılanan

48 "Seyyar Sergi", Milliyet, 11 Haziran 1926.

49 "Ticaret Vekili Rahmi Bey, dün Ankara'dan şehrimize geldi", Milliyet, 12 Haziran 1926.

50 Aynı yer.

51 "Seyyar Sergi bugün hareket ediyor", Vakit, 12 Haziran 1926. 
Gazi, teftişi gerçekleştirmek üzere Karadeniz’e davet edildi. Sergi komiseri Raufi Bey, geminin meşher ve satış reyonlarını gezdirerek Gazi’ye bilgi verdi. Sergi defterine "Sergi muvaffak olmuş bir eserdir. Bizde gayet iyi intibalar husule getirdi. Tarz-1 teşhir çok iyidir. Müteşebbislerini takdir ve tebrik ederim" ${ }^{52}$ satırlarını yazan Gazi, sergiden duyduğu memnuniyeti dile getirdi. Bu sırada, vapurda satış reyonunda görevli olan Ali Usta ve Sedefli Vasıf Bey, Gazi’ye değerli taşlardan mamul bir tespih ile fildişinden imal edilmiş bir sigara tabakası hediye etti. Ayrıca, Karadeniz Vapuru'nda gemi personeli ve misafirlere Gazi'nin onuruna bir öğle yemeği verildi. Karadeniz Vapuru, 13 Haziran'da Bandırma'ya hareket ederken, Gazi ve heyeti de Bandırma'da Seyyar Sergi'ye veda ederek Izmir'e hareket etti. ${ }^{53}$

Seyyar Sergi'de tütün standı sorumlusu olan Muhsin Selçuk (Severman) Bey, hatıralarında Gazi Mustafa Kemal Paşa'nın sergiyi denetlediği o günü şöyle anlatir:

“Karadeniz Vapuru, 'Seyyar Sergi' olarak hazırlanmıștı. Ben de bu Seyyar Sergi'deki tütün standının şefiydim. Bizim vapurda Mudanya İskelesi’nde iken Atatürk'ün şerefine bir ziyafet verildi. Bu fotoğraf (ziyafet fotoğrafi) o ziyafette alındı. Sergi'nin yöneticisi Manyasizade Raufi Bey'di. Ziyafette Gaziantep mebusu Remzi Bey, Galip Bahtiyar Bey, Gelal Esat Bey (Arseven) de vardı... Atatürk, iktisadi durumu düzeltmek için memleketimizi ve zenginliklerimizi Avrupa'da tanıtmak istemişti. Bunun için Karadeniz Vapuru'nda bir seyyar sergi düzenlemişti."

\section{Seyyar Sergi'nin Avrupa Seyahati}

Cumhuriyet tarihinin ilk seyyar sergi gemisinin kaptanlığını Lütfi (Topuz) Bey $^{55}$ üstlendi. Sefere bir süvari, bir ikinci kaptan, üç üçüncü kaptanla, tatbikat

52 Mustafa Kemal Paşa'nın yazısı için bkz. Ek.3.

53 "Seyyar Sergi nihayet yola çıkabildi" Milliyet, 13 Haziran 1926; "Seyyar Sergi bugün hareket ediyor", Vakit, 12 Haziran 1926; "Reis-i Cumhurumuz İzmir'e hareket etti", Vakit, 14 Haziran 1926.

54 Yılmaz Akkılıç, Atatürk ve Bursa, Nilüfer Akkılıç Kütüphanesi, 3. Baskı, Bursa 2009, s. 77-78.

55 Denizci bir babanın oğlu olan Lütfi Kaptan, 1886 yllında İstanbul'da doğdu. Bahriye'nin ardından Demirhisar torpidobotunun kumandanlığına atandı. Lütfi Kaptan; Trablusgarp, Balkan ve Birinci Dünya Savaşı sırasında Basra torpidobotunun kumandanlığını yaptı. 1919'da 33 yaşındayken kıdemli yüzbaşı rütbesiyle bahriyeden emekli olduktan sonra Seyr-i Sefain İdaresi'ne geçti. 1921 yllında 35 yaşındayken Gülcemal yolcu gemisinin süvariliğine getirilen Lütfi Kaptan, asıl büyük ününü bu yıllarda yaptı. Lütfi Kaptan, 1920 Aralık'ında Gülcemal gemisiyle Atlantik'i aşarak Amerika'ya ulaştı. Aynı gemiyle Amerika'ya üç sefer daha düzenledi. Sonraki yıllarda Seyr-i Sefain İdaresi'nin en büyük gemilerinden "Karadeniz", "İzmir" ve "Ege"nin süvariliğini üstlendi. Lütfi Kaptan, 1926 yllında Seyyar Sergi'ye ev sahipliği yapan ve Avrupa limanlarını turlayan Karadeniz Vapuru'nun süvariliğine getirildi. 1928'de İzmir, ardından Ege yolcu gemisinin süvariliğini üstlenen Lütfi Kaptan, 1932 yılında 46 yaşındayken vefat etti. Bkz. Eser Tutel, "Gülcemal'in Süvarisi Lütfi Kaptan", Tarih ve Toplum, Mart 1996, Cilt 25, Sayı 147, s. 149-156. Ayrıca bkz. 
görmek üzere yedi mülazım [güverte zabiti] kaptan, bir doktor, bir telsiz memuru olarak 15 güverte zabitiyle yedi makine zabiti iştirak etti. Kamara çalışanları, güverte ve makine adamlarının sayısı 125 idi. 47 kişilik Riyaset-i Cumhur Orkestrası, 95 kişilik Tertip Heyeti ve 18 kişilik iaşe çalıssanı ile birlikte gemide toplam 285 kişi mevcuttu. ${ }^{56}$

Gemide dikkat çeken yolcular arasında sergi komiseri Raufi Bey, yazar Celal Esat Bey (Arseven), istihbarat müdürü Bahtiyar Bey, şirketler komiseri Baha Bey, harici ticaret temsilcisi Halil Mitat Bey, coğrafya encümeni reisi General Pertev Bey, Gaziantep milletvekili Remzi Bey, orkestra şefi Miralay Zeki Bey, umumi kâtip Seyfettin Bey, posta müdürü Kenan Bey, ziraat uzmanı Zihni Bey, idare müdürü Mahmud Celal Bey, Akşam gazetesi temsilcisi Vala Nureddin Bey, Celal Esat Bey'in kızı ve Resimli Gazete'nin muhabiri Bedia Celal Hanım, Anadolu Ajansı temsilcisi Kemalettin Bey, demiryolları temsilcisi Eşref Bey, tütün inhisarı mümessili Semih Bey ve Hasan Ecza Deposu sahibi Hasan Bey bulunmaktaydı. ${ }^{57}$

Karadeniz Vapuru, programda olmamasına rağmen kömür ikmali için Cezayir'in Bonne (Anaba) limanı ile Polonya hükümetinin resmi müracaatı üzerine bu ülkenin Gidinya Limanı'na da uğradı. Fakat vapur, programda ilan edilmesine rağmen İngiltere'nin Liverpol, İtalya'nın Venedik ve Trieste, Rusya'nın Batum ve Odesa, Romanya'nın Köstence ve Bulgaristan'ın Varna limanlarına bazı nedenlerden dolayı uğrayamadı. Buna ilaveten, Karadeniz'in başlangıçta ABD limanlarına da uğraması düşünülmüşse de mesafenin uzaklığı ve yolculuğun ağır maliyeti gibi nedenlerden dolayı planlanan yolculuk gerçekleşmedi.

Karadeniz Vapuru'nun yaklaşı 3 ay süren seyahati boyunca ziyaret ettiği limanlar ve bu limanlardaki sergi faaliyetleri şöylece özetlenebilir:

\section{Bonne (Gezayir) 17.06.1926}

Karadeniz Vapuru'nun program dışı olarak gerçekleştirdiği bu ziyaretin amacı, kaliteli kömürleriyle bilinen Bonne Limanı'ndan kömür takviyesi yapmaktı. Seyyar Sergi, ilk kez burada görücüye çıktı ve Cezayir halkının beğenisine sunuldu. Türk imajının geçirdiği evrim ve özellikle kadın personelin çağdaş giyim tarzı, Araplar tarafindan şaşkınlıkla karşılandı. Arseven, Arapların gemi ziyaretini ve yaşadıkları şaşkınlığı anılarında şöyle anlatır: "Maaş almak için

Eser Tutel, Gemiler, Süvariler, İskeleler, s. 34-37. Lütfi Kaptan için bkz. Ek.4.

56 Gürsu, a.g.e., s. 18.

${ }^{57}$ Eser Tutel, Gemiler, Süvariler, Iskeleler, s. 32. 
tahsil şubelerine toplanan eyyam ve eramil kalkışmasıyla etrafımızı saran genç, ihtiyar, çoluk, çocuk bir sürü halkın nazarları, hep içimizde yüzü açık jüpü kısa Türk hanımlarına saplanıp kalmış, "Türk! Türk” diye yarı nefret ve yarı hayretle temaşaya dalmışlardı. Onlar bize, biz onlara acıyorduk. ${ }^{\prime 58}$

\section{Barselon[a] (İspanya) 20.06.1926}

Seyyar Sergi, Barselona Limanı'nda yoğun bir ilgiyle karşılandı ve 2 günde yaklaşık 11 bin kişi tarafindan ziyaret edildi. Bursa ipekleri, Hacı Bekir lokumları, pamuk ve tütün, İspanyolların en çok rağbet ettiği ürünler oldu. Fakat, Türkiye ile İspanya arasında bir gümrük anlaşmasının olmaması ve İspanya Hükümetinin koyduğu yüksek gümrük vergisi, ürünlerin satışını olumsuz etkiledi. ${ }^{59}$ Zeki Beyin idaresindeki Riyaset-i Cumhur Orkestrası'nın ziyaretçilere verdiği konser, İspanyollar tarafindan ilgiyle karşılandı. ${ }^{60}$

Barselona'da Seyyar Sergi'ye en çok rağbet gösteren ziyaretçiler, İspanya'da ikamet eden Türk tebaası Yahudiler oldu. Türkiye'nin Barselona Konsolosluğu, 4 Yahudi'yi tercüman olarak görevlendirdi. Yahudilerin, Türk devletini hala meşrutiyetle idare edilen bir devlet sanmaları ve cumhuriyetten bihaber olmaları, Türk basını tarafından şaşkınlıkla karşılandı. Yahudilerin kendilerini "Barselon'da Osmanlı kolonisi" diye tanıtmaları da başka bir şaşkınlık konusu oldu. ${ }^{61}$

\section{Le Havre (Fransa) 2.7.1926}

Gürsu'nun notlarına göre Seyyar Sergi, Le Havre'de Fransızlardan beklediği ilgiyi göremedi. Fakat yine de 2 günde 25.000 [2.500 olmalı] kişinin sergiyi ziyaret ettiği tahmin edildi. Gemi personeli, Havre Belediyesi’nde ağırlanarak kendilerine bir ziyafet verildi. Burada karşılıklı teati edilen nutuklardan sonra Riyaset-i Cumhur Orkestrası'nın konseri icra edildi. ${ }^{62}$

58 Celal Esat Arseven, Seyyar Sergi ile Seyahat Intibalan, Kitabevi, İstanbul 2008, s. 22.

59 "Seyyar Sergiye refakat eden muharririmizin intibaaları", Resimli Gazete, 17 Temmuz 1926. Ayrica bkz. "Seyyar Sergi ile giden muhabirimizin Barselon intihabatı", Cumhuriyet, 3 Temmuz 1926; "Seyyar Sergi Barselondan ayrilırken", Vakit, 7 Temmuz 1926.

60 "Seyyar Sergi Barselonda", Vakit, 24 Haziran 1926.

61 Kemalettin Kamu, "Seyyar Sergimiz İlk Durağında", Hakimiyet-i Milliye, 8 Temmuz 1926. Ayrıca bkz. "Seyyar Sergi ile birlikte giden Vakit muhabirinin mektubu, Seyyar Sergi Barselon'da nasıl karşılandı", Vakit, 6 Temmuz 1926.

62 Gürsu, a.g.e., s. 40. Ayrıca bkz. "Seyyar Sergi ile giden muhabirimizin mektupları", Cumhuriyet, 16 Temmuz 1926; "Seyyar Sergi Havre'de", Vakit, 5 Temmuz 1926. 


\section{Londra (İngiltere) 4.7.1926}

Karadeniz Vapuru, Türkiye'nin Londra sefiri Ferid Bey tarafindan karşıland. Londra'da 6 gün kalan Seyyar Sergi, bir gün Londra'nın ileri gelenlerine beş gün de genel ziyaretçilere açıld. Seyyar Sergi'yi yaklaşık 25 bin kişi ziyaret etti. Özellikle tütün, buğday ve fantezi eşyası, İngilizlerin en çok ilgisini çeken ürünler oldu. Sadece İbrahim Paşa ve Mahdumları Firması'na 1.500.000 liralık sipariş verildi. İnhisar (tekel) İdaresi, Türk tütünlerinin gördüğü rağbet üzerine Avrupa'da yeni şubeler açma kararı aldı. Hacı Bekir şirketi ve tütün inhisarı, kayda değer satışlar yaptı. ${ }^{63}$

\section{Amsterdam (Hollanda) 11.7.1926}

Karadeniz Vapuru, Türkiye'nin Lahey maslahatgüzar Esad Bey, konsolos Tahir Bey ve kançelar Nebil Bey tarafından karşılandı. Hollanda yapımı bir gemi olarak Amsterdam'da büyük ilgi gören Karadeniz Vapuru, ayrıcalıklı bir rıhtımda demirledi. 2 günde toplam 5.000 kişinin ziyaret ettiği serginin özellikle tütün standı yoğun ilgiyle karşılandı. Bedia Celal Hanım'ın aktardığına göre Amsterdam Belediye Başkanı, zarif ve çağdaş giyimiyle dikkat çeken kadın personele hayranlığını dile getirdi. Zeki Bey liderliğindeki Riyaset-i Cumhur Orkestrası, vapurda ve şehrin "Merkez Park"ında verdiği müzik ziyafetiyle Hollanda halkının takdirini kazandı. ${ }^{64}$

\section{Hamburg (Almanya) 16.7.1926}

Karadeniz Vapuru, Türkiye'nin Berlin büyükelçisi General Kemaleddin Sami Bey ve heyeti tarafindan karşılandı. Hamburg Hükümeti Başkanı Herr Peterrson, sergi heyetine belediye binasında bir ziyafet verdi. Ziyafette tarihi TürkAlman dostluğuna vurgular yapılırken iki ülkenin gelişen iktisadi ilişkilerine dikkat çekildi. Riyaset-i Cumhur Orkestrası, Hamburg’ta yaklaşık 8.000 kişinin dinlediği bir müzik ziyafeti verdi. Hannover Türk Fahri konsolosu Mösyö Hopman'in güneş çarpması nedeniyle Karadeniz Vapuru'nda vefat etmesi ziyaretin en üzücü olayı oldu. ${ }^{65}$

63 Bedia Celal hanım, "Seyyar Sergiden mektup", Resimli Gazete, 7 Ağustos 1926; "Sergi Londra'da nasıl karşılandı", Vakit, 16 Temmuz 1926; "Seyyar Sergi İngiltere'de nasıl karşlandı", Cumhuriyet, 21 Temmuz 1926; "Tütünlerimiz Londra'da rağbet gördü", Cumhuriyet, 24 Temmuz 1926.

64 Bedia Celal, "Seyyar Sergiden mektup", Resimli Gazete, 7 Ağustos 1926; Ayrıca bkz. Gürsu, a.g.e., s. 55-56; "Seyyar Sergi Amsterdam limanında", Vakit, 17 Temmuz 1926.

65 "Seyyar Sergimiz Alman sahillerinde selamlandı", Cumhuriyet, 17 Temmuz 1926; "Seyyar Serginin Hamburg'u ziyareti Türk-Alman dostluğunun teyidine vesile olmuştur", Cumhuriyet, 18 Temmuz 1926; Vala 


\section{Stockholm (İsveç) 21.7.1926}

Seyyar Sergi, Stockholm'de liman idaresi başkanı tarafindan karşılandı. Türk heyeti şerefine Stockholm Belediyesi'nde bir ziyafet verildi. Aynı gün Karadeniz Vapuru'nda İsveç sosyetesine 200 kişilik bir balo tertip edildi. Yoğun ilgiyle karşılanan sergi, üç gün zarfinda yaklaşık 7500 kişi tarafindan ziyaret edildi. ${ }^{66}$

\section{Helsinki (Finlandiya) 25.7.1926}

Karadeniz Vapuru, kötü hava şartlarına karşın Helsinki'de kalabalık bir halk kütlesi tarafindan karşılandı. Karşlayanlar arasında Finlandiya Dışişleri Bakanı da hazır bulundu. Riyaset-i Cumhur Orkestrası, ziyaretçilere Türk ve Finlandiya marşlarından harmanlanmış bir müzik demeti sundu. Gemiyi ziyaret edenler arasında çok sayıda Müslüman'ın bulunması sergi heyeti tarafindan ilgiyle karşlandı. ${ }^{67}$

\section{Leningrad (Sovyetler Birliği) 29.7.1926}

Seyyar Sergi, Leningrad'ta Rus güvenlik güçlerinin sıkı önlemleri altında ziyarete açıldı. Ziyaretçiler, Rus makamlarının kendilerine verdiği karneler eşliğinde gemiye alındı. Gemi personelinin kimlik kartları, yetkili organlar tarafindan mühürlenerek vizeye müsaade edildi. Gemideki fotoğraf makineleri, önlem amaçlı olarak mühürlendi ve ziyaret süresince bir kamarada alıkonuldu. Gemi kasasında bulunan paralar kontrol edildi ve geminin telsiz dairesi kapatıldı. Leningrad Ticaret Odası, Türk heyeti şerefine bir akşam yemeği düzenledi. Yemekte, iki ülke ilişkilerinin geliştirilmesi yönünde tarihsel vakalara vurgu yapan konuşmalar yapıldı. ${ }^{68}$

Rus yetkililer, Leningrad Limanı'nda sadece 75.000 liralık bir satı̧̧a izin verdi. Şekerlerden ve şekerlemelerden gümrük vergisi alınmadı. Yüksek vergiden dolayı Bursa kumaşları satılamazken, halı dairesi de kapalı tutuldu. En çok satışı kehribarcılar gerçekleştirdi. ${ }^{69}$

\footnotetext{
Nureddin, "Hamburg'ta Seyyar Sergi şerefine verilen ziyafet", Vakit, 18 Temmuz 1926; Bedia Celal Hanım, "Seyyar Sergiden Mektup", Resimli Gazete, 21 Ağustos 1926; Gürsu, a.g.e., s. 63-71.

66 Kemalettin Kamu, "Seyyar Sergimiz Stockholm Limanında", Hakimiyet-i Milliye, 2 Ağustos 1926. Ayrica bkz."Seyyar Sergi İstokholmde", Cumhuriyet, 24 Temmuz 1926; "Seyyar Sergide", Vakit, 26 Temmuz 1926.

67 Gürsu, a.g.e, ., s. 88-89.

68 Gürsu, a.g.e., s. 98-101.

69 "Seyyar Sergi Rusya'dan çıkarken", Cumhuriyet, 10 Ağustos 1926.
} 


\section{Danzig (Danzig) 1.8.1926}

Seyyar Sergi, serbest bölge statüsünde bulunan Danzig Limanı'nda Türkiye'nin Varşova Elçisi Yahya Kemal Bey tarafindan karşılandı. Sergiye gösterilen ilgi gayet sönük kaldı. Türk Dışişlerinden gelen talimat üzerine Karadeniz Vapuru'nun Polonya'nın Gidinya Limanı'na uğraması kararlaştırıldı. Bundan dolayı Danzig'deki mesai, daha çok Gidinya Limanı'na hazırlık şeklinde harcand. ${ }^{70}$

\section{Gidinya (Polonya) 3.8.1926}

Karadeniz Vapuru, ilk kez Gidinya Limanı'nda savaş gemilerinin refakatinde rıhtıma yanaştı. Kaptan Süreyya Gürsu, bu sıra dışı durumu Polonya'nın Türklere olan ilgisinin bir tezahürü olarak yorumladı. Sergi Heyeti, Gidinya Gazinosu'nda bir ziyafetle ağırlanırken Türk kadınlarının zarafeti ilgi odağı oldu. ${ }^{71}$ Serginin özellikle tütün standı, Polonya halkının yoğun ilgisiyle karşılaşt. ${ }^{72}$

\section{Kopenhag (Danimarka) 5.8.1926}

Seyyar Sergi, Kopenhag'ta kalabalık bir insan kütlesi tarafindan karşılandı. Riyaset-i Cumhur Orkestrası'nın Karadeniz Vapuru'nda çaldığı Türk ve Danimarka marşları, ziyaretçilerin coşkulu tezahüratıyla karşılandı. Sergiyi ziyaret edenlerden biri de Danimarka Dışişleri Bakanı Von Moltke idi. Sergiyi takdir eden Moltke, sergi idarecilerini evinde ağırlayarak kendilerine teşekkür etti. Buna karşıllk Tertip Heyeti, Karadeniz Vapuru'na davet ettiği Kopenhag seçkinlerine bir balo düzenledi. Danimarka basını, Moltke'nin davetine ve Seyyar Sergi'ye geniş yer ayırdi. ${ }^{73}$

\section{Anvers (Belçika) 10.8.1926}

Anvers, diğer limanlardan farklı olarak vasat bir kalabalıkla Seyyar Sergi'yi karşıladı. İki günlük zaman zarfinda yaklaşık 1.500 kişi sergiyi ziyaret etti. Belçika'da yaşayan Türklerin Tertip Heyeti'ni ziyareti, bu ziyaretin en hoş sürprizlerinden birisiydi. ${ }^{74}$

\footnotetext{
"Seyyar Sergi Dancig'te", Hakimiyet-i Milliye, 6 Ağustos 1926.

Gürsu, a.g.e., s. 108.

"Seyyar Sergi ile giden muhabirimizin mektubu", Vakit, 31 Ağustos 1926.

Gürsu, a.g.e., s. 116-119.

"Seyyar Sergi ile giden muhabir-i mahsusamızın mektupları", Vakit, 2,4 Eylül 1926.
} 


\section{Marsilya (Fransa) 21.8.1926}

Karadeniz Vapuru'nun Marsilya ziyareti, o günlerde Türkiye ile Fransa arasında bir kriz yaratan Bozkurt-Lotus Davası'ndan dolayı gerilimli başladı. Karadeniz'in gelmesinden kısa bir süre önce Marsilya'da Ermeni lobileri tarafindan Türk karşıtı bir miting düzenlendi. Bunun üzerine Türk makamları, Karadeniz'i Marsilya'ya uğramaması yönünde bir telgrafla uyardı. Ancak, telgrafin geç gelmesi bu ihtiyati tedbiri ortadan kaldırdı. Sonuçta Karadeniz'in planlandığı gibi Marsilya'da kalmasına karar verildi fakat bazı güvenlik tedbirleri alınd. Ziyaretçilerin arasına karışabilecek provokatörler için geminin önemli bölümleri kontrol altında tutuldu. Makine ve dümen daireleri, köprü üstü, miyar pusula kısmı, seyir kamarası ve buna benzer hassas mekanlar kilitlendi. Seyyar Sergi’nin Marsilya ziyareti oldukça sönük geçti. Herhangi bir tören, konser veya ziyafet düzenlenmedi. Gemi personeli, mola süresince gemiden ayrılmadı. Buna rağmen yaklaşık 1.500 kişinin sergiyi ziyaret ettiği görüldü. ${ }^{75}$

\section{Genova (İtalya) 24.8.1926}

Karadeniz Vapuru, Cenova'da İtalyan devlet ricali ve büyük bir kalabalık tarafindan karşılandı. Cenova Belediye Başkanı, Gazi Mustafa Kemal Paşa hakkında; Sergi Heyeti Başkanı Raufi Bey de İtalya kralı ve Musolini hakkında sitayişkar nutuklar irad etti. Sergi, iki günde yaklaşık 1000 kişi tarafından ziyaret edildi. $^{76}$

\section{Napoli (İtalya) 27.8.1926}

Karadeniz Vapuru, Türkiye'nin Roma Büyük Elçisi Suad Davaz Bey ve bir İtalyan heyeti tarafindan karşılandı. Riyaset-i Cumhur Orkestrası, ziyaret boyunca Türk ve Faşist İtalyan marşlarını çalarak ziyaretçileri selamladı. Sergi, iki günde yaklaşık 2000 kişi tarafindan ziyaret edildi. ${ }^{77}$

Napoli ziyaretiyle birlikte Avrupa turunu tamamlayan Karadeniz Vapuru, 4 Eylül 1926'da Çanakkale'ye geldi ve 3.5 saat boyunca halkın ziyaretine açıldı. Gemi personeli tarafindan okunan dualar, Çanakkale şehitlerinin aziz ruhlarına ithaf edildi. Bu sirada Seyr-i Sefain Genel Müdürü Sadullah Bey, bir telgrafla gemi personelini başarılı mesaisinden dolayı tebrik etti. ${ }^{78}$

75 Gürsu, a.g.e., s. 142-144. Ayrıca bkz. "Seyyar Sergi İstanbul'a Avdet Ettikten Sonra", Resimli Gazete, 18 Eylül 1926.

76 "Seyyar Sergi", Vakit, 27 Ağustos 1926.

77 Gürsu, a.g.e., s. 157-158. Ayrıca bkz. "Seyyar Sergi Napoli'de", Hakimiyet-i Milliye, 31 Ağustos 1926.

78 "Seyyar Sergi", Vakit, 5 Eylül 1926 
Seyyar Sergi vapuru Karadeniz, 12 Haziran 1926 tarihinde başladığı Avrupa turunu 5 Eylül 1926 tarihinde İstanbul'da noktaladı. Saat 11.30'da Galata Rıhtımı'na yanaşan gemi, kalabalık bir halk kütlesinin coşkun tezahüratıyla karşılandı. Geminin üç gün boyunca Tayyare Cemiyeti menfaatine halka açılmasına ve son gün bir müsamere tertip edilmesine karar verildi. ${ }^{79}$ Seyr-i Sefain İdaresi, Seyyar Sergi'nin başarısından dolayı Lütfi Kaptan’ı 1000 ve geminin birinci makinisti İsmail Beyi 800 lira ile ödüllendirdi. ${ }^{80}$

Karadeniz, 86 gün 22 saat süren sefer boyunca Akdeniz, Atlantik, Kuzey ve Manş denizleriyle Baltık Denizini dolaştı. Bu süre zarfinda 12 ülkenin 16 limanını ziyaret edildi. Gemi, 40 gün 16 saatini seyretmekle ve 46 gün 6 saatini liman konaklarında geçirdi. Limanlara giriş ve çıkışlarda kullanılmak üzere 44 yabancı kaptan görevlendirildi. Bütün seferde 9.996 mil kat edildi, 2.778 ton kömür ile 971 ton tatlı su sarf edildi. Gemide, 16 balo ve yemek verilirken, hariçte de 36 ziyafete iştirak edildi. Seyyar Sergi'nin masrafi tahminen 600 bin ve sergiyi gezen toplam ziyaretçi de yaklaşık 65 bin olarak kaydedildi. ${ }^{81}$

Karadeniz Vapuru, seyahati boyunca bazı meteorolojik sorunlarla karşılaştı. Gemi, gidiş rotasında Akdeniz'de Bona ile Barselona limanı arasında kuvvetli bir firtınaya yakalandı. Fırtına, gemi personeli ve yolculara arasında paniğe neden oldu. ${ }^{82}$ Kuzey ülkelerinde, Atlantik ve Kuzey Denizi'nde sert rüzgar ve orta dereceli dalgaların dişında ciddi bir hava muhalefetine rastlanmadı. Geminin dönüş rotasında Portekiz ile İspanya sahilleri açıklarında etkili olan kuvvetli sis, yaklaşık 20 saat sürecek olan müteyakkız ve kontrollü bir seyire neden oldu. ${ }^{83}$

\section{Seyyar Sergi'nin Türk Basınında Yankıları}

Seyyar Sergi, henüz üç yıl önce bağımsızlığını kazanan genç Türkiye Cumhuriyeti için yeni bir olguydu. Gerçi, uluslararası sergiler hususunda Osmanlı Devleti’nden alınan güçlü bir mirasa sahip olunsa da Seyyar Sergi projesi, yeni devlet için yabancı bir deneyimdi. Ticaret Vekaleti'nin seyyar sergi projesini resmen açıklamasıyla birlikte kamuoyunda hummalı bir tartışma başladı. Türk

79 "Seyyar Sergi dün avdet etti", Vakit, 6 Eylül 1926. Gazetenin haber küpürü için bkz. Ek.6.

80 "Seyyar Sergiyi götürüp getiren adam", Vakit, 8 Eylül 1926.

81 Gürsu, a.g.e., s. 169.

${ }^{2}$ Celal Esat Arseven, geminin yaşadığı hava muhalefetini şöyle betimlemiştir: "Böyle bir hava ile çıkmak münasebetsizdi; fakat çıkmamak kaptanın elinde bile değildi. Çizilmiş bir program, sergi için tayin edilmiş bir gün ve Barselon (Barselona) rıhtımlarında bizi bekleyen bir halk vardı. Artık sallanacak ve icap ederse Ertuğrul gibi memleket şerefine batacaktık" Bkz. Arseven, a.g.e., s. 24.

83 Gürsu, a.g.e., s. 24,33. 
kamuoyu, Avrupa'nın medeni ülkelerine yönelik olarak hazırlanan seyyar sergi fikrini başlangıçta ihtiyatla karşıladı. Türk basını, seyyar serginin organizasyonu ve sonuçlarının başarısı hususunda üçe bölünmüştü. Bunlar; Seyyar sergi fikrine destek vermekle birlikte başarısının bazı şartlara bağlı olduğunu düşünenler, sergi fikrini her yönüyle destekleyenler ve sergiyi küçümseyenler idi.

Haftalık Meslek gazetesi, Türkiye’ye oldukça pahalıya mal olacak serginin ülkeye yapması beklenen katkıy sorguluyordu. Memlekette ihtisasa yönelik olarak meslek ve iktisat teşkilatlarının olmadığını vurgulayan gazete, serginin uzman eliyle değil de belki de memur eliyle düzenleneceğini ve bundan dolayı faydalı olmayacağı kanaatindeydi. "En büyük faidesi olsa olsa, bizim bu işde de ne kadar metodsuz hareket etdiğimizi bize ısbat etmek olabilir” diyen gazete, İzmir'de yayımlanan Ticaret gazetesinin aynı yönde yazdığı satırları sayfasına taşıyordu. Gazete, Seyyar Sergi deneyiminden önce dahilde bir sergi düzenlenmesi gerektiğini öğütlüyor ve bu serginin şu hususları içermesi gerektiğini vurguluyordu:

1. İhraç ettiğimiz eşya ve maddelerin en iyi ambalaj tarzlarını,

2. Muhtelif ürünlerin en istenen işlenme şekil ve usullerini,

3. Broşür ve kataloglara kadar reklamın bütün çeşitlerine ait modelleri ve numunelerini,

4. Üretim ve ticaret hayatımıza girmesi istenen usullere ait tedbir ve çareleri. ${ }^{84}$

Gazete, özellikle Türk tüccarının uluslararası ticarette dikkat çeken ambalaj tekniği ve pazarlama konusundaki amatörlüğüne odaklanıyordu. Gazeteye göre, bozuk ambalaj tekniğiyle pazarlanan ürünler, kalite değerinin altında kalıyor ve ticaretimize ciddi zararlar veriyordu. Örneğin, yabancı ülkelere pazarlanan dünyaca ünlü Türk tütünleri, buralarda yeniden ambalajlanıp Amerika ve Avrupa'ya satılıyordu. Bunun nedeni, kötü ambalaj tekniği ve ihracatın yapıldığı ülkelerin arzu ve ihtiyaçlarının dikkate alınmamasıydı. ${ }^{85}$

Vakit'te, gazete muhabirinin Türkiye'nin İtalya'da bulunan dış ticaret temsilcisi Ali Muhtar Beyle yaptığı röportaja yer veriliyordu. Yazıda Ali Muhtar Bey, İtalyan iş çevrelerinin Türk seyyar sergisini merakla beklediklerini ve serginin İtalya limanlarında itibar göreceğini vurguluyordu. Ayrıca, "Ben vapurumuzun gelmesinin mahsulatımızın teşhir edilmesinden ziyade tüccarımızın Avrupa

84 "Harice Göndereceğimiz Seyyar Sergi Hakkında", Meslek, 14 Temmuz 1925, Sayı 31, s. 11.

85 Aynı yer. 
tacirleriyle görüşebileceklerine hizmet edeceğinden seviniyorum. Malımız kadar kendimizi de tanıtmağa ve karşımızdakileri tanımağa mecburuz. Mahsulatımızın seyyar sergi ile teşhiri kafi değil. Mümessilliklerde, şehbender hanelerimizde birer numune sergileri tesisi lazımdır." diyerek reklama ve sürekli sergilerin gerekliliğine dikkat çekiyordu. ${ }^{86}$

Şehremaneti Mecmuası'nda ayrıntılı bir değerlendirme yapan Ali Suad Bey, sergiyi özellikle İstanbul ölçeğinde değerlendiriyor ve teşhir edilen ürünlerle ilgili geniş bilgi veriyordu. Sergiyi "mütalaaya, tedkike, tahlile mecburuz" diyerek öz eleştiri daveti yapan yazar, Ali Muhtar Bey’in yukarıda işaret ettiği sürekli sergilere vurgu yapiyordu:

"Bir ikincisini, üçüncüsünü tanzime, memleketimizde bir sabit nev'ini yapmağa ve hatta ufakça mikyasta daimi salon ve daireler tesisine muhtacız. Ticaret ahkamı mucibince limanda "serbest mıntıka" usulünü kabul ederek orada ihracat eşyamızın bütün numunelerini buralı ve Avrupalı tacirler ve komisyonculara daima arz ve teşhirde, tuvalet ve ambalajlarını orada yapmakta geç kalmış olduğumuzu da bu münasebetle burada itiraf etmek elbette hakşinaslıktır"87

Seyyar Sergi'ye tam destek veren ve Bedia Celal Hanım'ı Karadeniz Vapuru'nda hususi muhabir olarak görevlendiren Resimli Gazete, sergiye ekonomik kazanımlardan ziyade çağdaş Türkiye'ye ayna tutacak bir reklam vasıtası olarak bakıyordu. Gazeteye göre sergi, Avrupa halkının Türk milleti hakkında asırlara dayanan önyargılı ve mesafeli bakışını değiştirecek, "İnkılap ve Cumhuriyet Türkiyesi” hakkında bilgilenmesini sağlayacaktı. Avrupa'nın gözünde Türk milleti, Osmanlı'dan gelen bir alışkanlıkla hala bir "silah milleti" olarak görülmekteydi. Türk milleti, "belki ince ve yüksek bir zeka ile mücehhez olduğu için silahina ve istiklale aşık bulunduğunu ancak böyle vasıtalarla cihana ispat edebilirdi."” Gazetenin şu ifadeleri dikkat çekicidir:

“Türkler, son zamanlara kadar Avrupa'ya yalnız ordu gönderdiler. Denizden İspanya'ya ve Cezayir sahillerine, karadan Viyana kalelerine kadar giden Türklerin ellerinde kılınç vardı. Bundan dolayıdır ki, bugünkü medeni alem bizi hala muharib sanatımızla, münhasıran harb adamı mahiyetiyle tanırlar. Avrupa'ya doğru en son giden Türk kafilesi yine bir ordu, Enver Paşa'nın Almanlara ikram ettiği kıymetli bir Türk ordusu idi. Seyyar sergi bir heyet-i keşfiye addedilebilir. Bu keşifler heyeti bize iktisad mübarezesinde [mücadelesinde] nasıl hazırlanmamız

86 Kamuran, "Ticaret-i Hariciyemiz teşkilata muhtaçtır", Vakit, 8 Nisan 1926.

${ }^{87}$ Ali Suad, "Seyyar Sergimiz münasebetiyle", Şehremaneti Mecmuası, Temmuz 1926, Sayı 23, s. 436-44. 
lazım geleceğini öğretecek. Avrupa'ya da Türk sanat ve ticaret ilmi hakkında hiç olmazsa asgari bir fikir götürecektir"

Seyyar Sergi, gündeme gelmesinden itibaren bazı basın organlarında temkinli hatta istihzai bir gülümsemeyle karşılandı. Ünlü karikatür dergisi $A k b a b a$, Seyyar Sergi'nin ilan edilen fakat defalarca iptal edilen programını hicveden yayınlar yapıyordu. Bunlardan birinde arkadan bir gülleyle bağlanmış Karadeniz Vapuru'nu önden bir salyangozun çekmeye çalıştı̆̆ı oyuncak dükkanına benzeterek karikatürize ediyordu. Karikatürün üstünde; "Gazetelerden: Seyyar sergi, bugün kalktı, yarın kalkıyor, öbür gün kalkacak", altta ise "Seyyar serginin gittiğinin resmidir" ibareleri yer alıyordu. ${ }^{89}$

Sergi hakkında kamuoyunu düzenli olarak aydınlatan Cumhuriyet, Galata Rıhtımı'nda son kez görücüye çıkan seyyar sergiyi organizasyon ve teşhir noktasında eleştiriyordu. Gazete, serginin "heyeti umumiyesi itibarıla bu yolda ibzal [harcanan] edilen emek ve masarifata tekabül edecek bir derecede" olmadığ kanaatindeydi. Seyyar Sergi'yi, "Memleketimize aid mamulat, mahsulat ve masnuatı Avrupa limanlarında Türklüğün yüzünü ağartabilecek bir şekilde teşhir için hazırlanan bir propaganda vasıtasından ziyade, alelade eşya teşhir eden bir pazarı ve harici manzarası itibarıyla da ara sıra limanımıza uğrayan Romanya vapurları kabilinden bir tenezzüh [gezinti] gemisini andırmaktadır" diye özetleyen gazete, Karadeniz’i de özgün olmayan bir "oyuncak dükkân”'ına benzetiyordu. ${ }^{90}$

Seyyar Sergi'yi ihtiyatla karşlayan gazetelerden Milliyet, Cumhuriyet'in izlenimlerine yakın bir çizgide değerlendirme yapıyordu. Gazete, Ticaret Vekili Rahmi Bey'in seyyar sergiyi teftişini ayrıntılı bir betimlemeden sonra kendi kanaatini şöyle açıklıyordu: "Vapur, uzun bir seyahatten ziyade mesela Marmara'da bir tenezzühe hazırlanmış ve süslenmiş bir haldedir. Fakat, serginin istihzaratı [hazırlıkları], şimdiye kadar geçen uzun bir zamana rağmen hala ikmal edilememiştir. Hatta vapurun iç ve dış kısımlarının telvinatına [boyanmasına] dün dahi devam edilmiştir. Sonra her meşherdeki eşya yerli yerine tamamen yerleştirilmiş de ğildir." 91

Başlangıçta Seyyar Sergi'yi tartışan ve bu hususta farklı görüşlere bölünen Türk kamuoyu, Karadeniz Vapuru’nun dönüşüyle birlikte serginin kazandığı

\footnotetext{
"Seyyar Sergi Avrupa yollarında", Resimli Gazete, 12 Haziran 1926, s. 2.

Akbaba, 10 Haziran 1926. Karikatür için bkz. Ek.5.

"Seyyar Sergi nihayet gidebildi", Cumhuriyet, 13 Haziran 1926.

91 "Ticaret Vekili Rahmi Bey, dün Ankara'dan şehrimize geldi", Milliyet, 12 Haziran 1926.
} 
başarıya odaklanmıştı. Türk basını, serginin yabancı limanlarda gördüğü ilgiye ve yeni Türk imajının Avrupa kamuoyunda yarattığ ilgiye dikkat çekiyordu.

Seyyar Sergi hakkında ilk resmi değerlendirme, Ticaret Vekaleti namına sergiye iştirak eden Dış Ticaret Müdürü Halil Midhat Bey'den geldi. Serginin maddi ve manevi kazanımlarının büyük olduğuna işaret eden Halil Midhat Bey, serginin ecnebilerin Türk milleti hakkındaki "fena fikirlerini tashih" ettiğini ve Türklüğe karşı takdir uyandırdığını vurguladı. Onun şu sözleri seyyar sergi'nin özeti gibidir:

"Ticaret Vekaleti, bu sergiyi tertip etmekle mahsulat ve emtiamız harice daha iyi tanıttırmak, ticaretimizi inkişaf ettirmek gayesiyle hazırladı. Mallarımız tüm ülkelerde büyük bir rağbet gördü. Özellikle, tütün, kuru yemişlerimiz, pamuk, kehribar, ipekli, mensucatımız, halılarımız, Hereke mamulatı şekerlemelerimiz takdir ve rağbet gördü. Dokuz cins eşyamız için farklı dillerde hazırlanan risaleler ilgiyle okunmuştur. Muhtelif şehirlerde üretim yapan tüccarımızın adresleri istenmiş ve hatta siparişler verilmiştir. Ülkelerin ticari tesis ve fabrikaları gezildi. Bunlar hakkında notlar alındı ve memleketimizde olabilecek girişimler hakkında bilgi alındı. Riyaset-i Cumhur orkestrasının verdiği konserler ilgiyle karşılandı. Şerefimize verilen birçok resmi ziyafetlerde hanımlarımız Türk kadınlığının nam ve şanını âlâ eylemiştir"

Yıllar sonra Seyyar Sergi hatıralarını kaleme alan Karadeniz'in 2. Kaptanı Süreyya Gürsu, serginin bir ilk olması, iktisadi kazançları, denizcilik ve düzenleme kabiliyeti gibi hususlarda "muvaffak olmuş" değerlendirmesini yapıyordu. Fakat Gürsu, serginin asıl başarısının ticari ve iktisadi çıkarlardan ziyade Avrupa kamuoyunda yaratmış olduğu yeni Türk imajı olduğunu vurguluyordu:

"Her şeyden evvel, seferimizin Avrupa şehirlerinde bıraktığı güzel tesir ve hatıralar, bilhassa Baltık Denizi'ndeki Şimal memleketlerinde ölçülemeyecek derecede şümullü [geniş] ve derin olmuştur. Türk sancağı, şimdiye kadar görülmediği bu uzak diyarlarda, muvaffakiyetle ve şerefle dalgalandırılmış, temiz bir geminin cana yakın insanları, her gittiği yerde pek hararetli bir istikbal görmüştür. İşte bu sebepledir ki Türklük hakkında bin türlü yanlış telakkilerle meşbu [dolmuş] bulunan bir kısım Avrupalılar, her şeyden evvel kendilerine benziyen, kendileri gibi konuşan insanlarla karşılaşmışlar, temiz bir gemi içinde kötü zihniyetlerini pek çabuk giderebilecek yüksek bir varlık bulmuşlardı»”93

\footnotetext{
92 "Seyyar Sergi dün avdet etti", Vakit, 6 Eylül 1926.

93 Gürsu, a.g.e., s. 171.
} 
Seyyar Sergi’nin başarısını kanıtladığına dikkat çeken Vakit, serginin başlangıçta plan dahilinde olan fakat "bazı mülahazalardan” dolayı gidemediği Karadeniz'in Odesa, Batum, Köstence ve Varna limanlarına mutlaka gitmesi gerektiğini vurguluyordu. Gazeteye göre, Türkiye ile iktisadi ilişkileri zayıf olan ülkelere bile uğrayan serginin, daha güçlü ekonomik ilişkiler içinde bulunduğumuz ülke limanlarına gitmemesi doğru olmazdı. Karadeniz Vapuru, İstanbul'a demirlemeden bu ziyareti gerçekleştirmeliydi. Bunu sonraya bırakmak, büyük bir hazırlık ve finansal kaynak gerektiren yeni bir sergiyi imkansız hale getirebilirdi. Gazete, 'Sergiyi Leningrad'dan ziyade Odesa ve Batum'a, Helsingford'dan ziyade elbette Köstence ve Varna’ya göstermelidir" diyerek Karadeniz limanlarının önemine dikkat çekiyordu. ${ }^{94}$

Milliyet, serginin başarısını 'Giderken 'asgari mahcubiyet' istenen sergi, bilakis 'azami muvaffakiyet' temin ederek gelmiştir” cümlesiyle ifade ediyordu. Gazetenin şu ifadeleri, Türk basınının seyyar sergiye bakışını özetliyordu: "Bundan iki ay yirmi bir gün evvel bazı gazetelerimizin 'gitti, gidiyor, gitmemesi lazımdır, eyvah gidiyor' gibi memnuniyet ifade etmeyen tenkidleri arasında limanımızdan hareket eden "Karadeniz" Seyyar Sergi vapuru yine gazetelerimizin fakat bu defa memnuniyetle 'geldi, geliyor' haberleri arasında dün saat on birde limana avdet etmiştir." 95

Hükümete yakın Hakimiyet-i Milliye, Karadeniz Vapuru'nun dönüşünü "ziyaret ettiği memleketlerde çok iyi intibalar birakarak dönen Karadeniz Vapuru" ifadesiyle kamuoyuna duyuruyordu. ${ }^{96}$ Gazete, Seyyar Sergi'nin başarısını "Türk matbuatı serginin muvaffakiyetinden bahsediyor" satırlarıyla vurguluyordu. ${ }^{97} \mathrm{Bu}$ haberlerde ayrıntıya ve yoruma girilmemesi dikkat çekicidir. Gazetenin konuyla ilgili ayrıntılı haberi 9 Eylül 1926 tarihli nüshasında "Seyyar sergimiz hakkında İtalyan matbuatı ne diyor?" başlıklı yazıda yayımlanıyordu. İtalyan Il Secolo gazetesinin haberine dayandırılan yazıda, Türk seyyar sergisinin Cenova Limanı'nda düzenlenen karşılama törenindeki izlenimlere yer veriliyordu. Yazıda, İtalyanların özellikle Osman Zeki Beyin idaresindeki Riyaset-i Cumhur Orkestrası'nın çaldığı parçalara hayran kaldığı ve serginin en fazla "şark köşesi”" ne ilgi gösterdiği vurgulanıyordu. ${ }^{98}$

94 "Seyyar Sergi ile giden muhabir-i mahsusamızın mektupları, Vakit, 4 Eylül 1926.

95 "Seyyar Sergi dün avdet etti", Milliyet, 6 Eylül 1926.

96 "Seyyar Sergi İstanbul'da", Hakimiyet-i Milliye, 6 Eylül 1926.

97 "Seyyar Serginin muvaffakiyeti", Hakimiyet-i Milliye, 7 Eylül 1926.

98 "Seyyar sergimiz hakkında İtalyan matbuatı ne diyor?", Hakimiyet-i Milliye, 9 Eylül 1926. 
Seyyar Sergi'ye hazırlık safhasında en güçlü muhalefeti yapan Cumhuriyet ve Akşam gazeteleri, diğer gazeteler gibi güçlü bir tonla ifade etmese de, serginin Avrupa turunu başarılı buluyordu. Cumhuriyet, "Seyyar sergi gayesinde muvaffak olmuştur"99 derken, Akşam gazetesi de "Karadeniz Vapuru, Avrupa'da üç ay devam eden seyahati esnasında uğradığı bütün limanlarda gayet müsaid intibalar uyandırmıştı»" 100 ifadelerini kullanıyordu.

Daha önce Seyyar Sergi'yi geniş çapta değerlendiren Ali Suad, sergi'nin başarısını takdir etmekle birlikte kamuoyuna iki noktada sorgulama yapma tavsiyesinde bulunuyordu. Birinci hususta, serginin iktisadi boyutta neler kazandırdığı ve gelecek için ne kadar güven verdiği sorgulanmalıydı. Diğer hususta, serginin hazırlık ve teşhir sürecinde ne kadar hazırlanabildiği tartışılmalıydı. Ali Suad, sergide teşhir edilen ürünleri tanıtan matbu evrak ve broşürlerin yetersiz olduğu kanaatindeydi. Halbuki müşteri, böyle seyyar komisyonculuğun olduğu sergilerde henüz tanımadığı satıcılar hakkında ayrıntılı bilgiye ihtiyaç duymaktadır. Ali Suad'ın eleştirdiği başka bir konu da Seyyar Sergi gemisinin seyahat planında yaşanan aksaklıklar ve görevlilerin yetersizliği idi. O’na göre, bazı limanlarda oluşan yoğunluğa karşın geminin erkenden ayrılması kabul edilemezdi. Ayrıca, gemide ürün teşhiri yapan görevlilerin ameli ve ticari bir uzmanlıktan yoksun olmaları büyük eksiklikti. Lisan bildikleri halde müşterilerle iletişimde sıkıntı yaşayan tercümanlar da başka bir sorundu. Yine de Ali Suad, Seyyar Sergi'nin genel itibarıyla başarılı olduğunu, bahar aylarında Mısır, Suriye ve Filistin sahillerini dolaşarak Amerika'ya kadar uzanması gerektiğini savunuyordu. ${ }^{101}$

\section{Sonuç}

Avrupalı devletler, XIX. yüzyılın ikinci yarısından itibaren düzenledikleri uluslararası sergilerle ekonomik ilişkilerde yeni bir çı̆̆ır açtı. Uluslararası sergiler, devletlerin ekonomik ve mali kapasitelerini yansitırken ayn zamanda onların siyasi arenada kullandıkları bir yumuşak güç unsuru haline geldi. Böylelikle, ekonomik amaçlarla dünya siyasetine giren sergiler, zamanla devletlerin kamu diplomasisine hizmet eden başat güç unsurlarına dönüştü. Bir Avrupalı devlet olma kimliğini sürdürmek isteyen Osmanlı Devleti de uluslararası sergilere katılma hususunda güçlü bir irade ortaya koydu. Bu bağlamda önemli sergilere katılan ve 1863'te

\footnotetext{
99 "Karadeniz geldi", Cumhuriyet, 6 Eylül 1926.

100 "Seyyar Sergi geldi", Akşam, 6 Eylül 1926.

101 Ali Suad, "Seyyar Sergimiz Hakkında", Şehremaneti Mecmuası, Sayı 25, Eylül 1926, s. 626-630.
} 
İstanbul'da düzenlediği uluslararası sergiyle rüştünü ispatlayan Osmanlı Devleti, bilgi ve birikimleriyle Türkiye Cumhuriyeti’ne ciddi bir miras devretti.

Lozan Barış Antlaşması'yla siyasi bağımsızlı̆̆ını kazanan Türkiye Cumhuriyeti, ekonomik anlamda da bağımsızlı̆ıını kazanmak ve Avrupalı devletler nezdinde saygin bir konum edinmek azmindeydi. Cumhuriyetin ilanıyla birlikte birçok alanda hayata geçirilen devrimler, yeni Türk devletini medeniyet aleminde yükseltmeyi hedefliyordu. 1926'da gerçekleştirilen Seyyar Sergi, çok yönlü bir çağdaşlaşma hamlesi olarak gündeme getirildi. Sergi, temel anlamda Türk ekonomisini Avrupa'da tanıtmayı ve geliştirmeyi hedeflerken, aynı zamanda yeni Türk imajını da medeni dünyaya göstermeyi amaçlıyordu.

Seyyar Sergi, 1925 yllında TBMM'de cereyan eden bütçe görüşmelerinde Ticaret Vekili Ali Cenani Bey tarafından gündeme getirildi. Sergi, ülkede açılması planlanan bir ticaret sergisinin ağır maliyetine karşı bir alternatif olarak önerildi. Mustafa Kemal Paşa tarafından onaylanan sergi projesi, ülke sathına yayılan geniş çaplı bir hazırlık döneminde olgunlaştırıldı. Proje planı, zaman içinde yapılan bir çok değişiklik ve ilavelerle son şeklini aldı. Seyyar Sergi; Ticaret Vekaleti, Seyr-i Sefain İdaresi ve İstanbul Ticaret Odası'nın ortak mesaisi olarak hayata geçirildi.

Seyyar Sergi, hazırlık aşamasında Avrupa'da bile yankı bulurken, Türk kamuoyunda beklenen desteği ve ilgiyi göremedi. Sergi fikrini ihtiyatla karşılayan Türk basını, serginin organizasyonu, standartları ve muhtemel başarısı hususunda hemfikir değildi. Bazı basın organları, sergi fikrini hararetle desteklerken bazıları da istihzai bir tavırla sergiyi karşıladı. Bazı yayınlar da ülkenin henüz uluslararası bir sergiyi hazırlayacak bilgi ve deneyimden yoksun olduğundan hareketle sergiye şiddetle muhalefet etti. Serginin planlanan hareket tarihinin defalarca ertelenmesi, basında eleştirilerin dozunu daha da artırdı. Fakat, Avrupa seyahatini sorunsuz tamamlayan Seyyar Sergi, İstanbul'a dönüşünde Türk basını tarafindan başarılı bulunarak takdir edildi.

Türk ticaret çevrelerinin Seyyar Sergi'ye olan ilgisi, bazı nedenlerden dolayı beklenenin altında kaldı. Tüccar, organizasyon ve iktisadi kazanımlar noktasında sergiyi yetersiz ve sıradan buluyordu. Tüccarın işletmesini terk edip uzun bir süre Avrupa'da kalmaya cesaret edecek bir deneyim ve özgüvenden yoksun oluşu da bu ilgisizliğin nedenlerinden biriydi. Tüccara sağlanan değişik avantaj ve kolaylıklara rağmen, yeterli sayıda iş adamı sergiye rağbet etmedi. Türk sanatını ve imalatını yansıtan ürünler, ülkenin farklı bölgelerinden alınarak özenle sergiye taşındı. Teşhir edilen mallar, Türklere özgü otantik özellikler taşısa da, genelde Türk milletinin 
mütevazi yaşam tarzını yansıtan ürünlerdi. Bu tevazu, ard arda yaşadığı yıkıcı savaşlardan çıkan Türk milletinin ekonomik kapasitesinin de bir yansımasıydı.

Karadeniz Vapuru'nun Avrupa seyahati, Türk denizcilik bilgisi ve kabiliyeti bakımından oldukça başarılı geçti. Liyakatli Türk kaptanlarının idaresinde seyreden Karadeniz, Avrupa'nın tehlikeli denizlerini maharetle aşarak hedefine sabırla ilerledi. Seyyar Sergi, Türk kamuoyundan farklı olarak Avrupa kamuoyunda daha büyük yankılar uyandırdı. Bir kaç liman istisna edilirse, Avrupalılar, sergiye yoğun şekilde ilgi gösterdi. Ünlü Türk tütünleri, Hacı Bekir lokumları ve oryantal işlemeli kehribarlar, en çok rağbet gören ürünler oldu. Diğer yandan, sergiye eşlik eden Türk kadınlarının zarafeti ve şı giyim tarzı, Avrupalıların Türkler hakkında müzminleşen olumsuz imajın silinmesine katkı sağladı. Karadeniz Vapuru'nda Riyaset-i Cumhur Orkestrası'nın eşliğinde Avrupalı seçkinlere verilen balolar, çağdaş Türk imajının tanıtılması bakımından önemli firsatlar oldu.

Seyyar Sergi, Türk denizcilik tarihinde haklı bir gurur ve başarı sayfası olarak kayıtlara geçti. Ticari kazanımları önemli olmakla birlikte serginin asıl başarısı, genç Türkiye Cumhuriyeti'nin çağdaşlaşma yolunda ortaya koyduğu kararlı ve sarsılmaz iradedir. Mütevazi Karadeniz Vapuru, Mustafa Kemal Paşa liderliğindeki Türk milletinin yeniden dirilişinin ve medeniyet alemiyle kucaklaşma azminin parlak bir sembolü oldu. 


\section{KAYNAKLAR}

\section{ARŞIV BELGELERI}

Başbakanlık Cumhuriyet Arşivi, 180.09.52.262.1.92.

\section{RESMI YAYINLAR}

\section{T.B.M.M Zabit Ceridesi.}

İçtima 82, 19.3.1341.

İçtima 91, 1.4.1341.

İçtima 63, 28.2.1926.

\section{Resmi Gazete}

Sayı 324. Tarih 17.3.1926.

\section{KITTAPLAR}

Akkılıç, Yılmaz, Atatürk ve Bursa, Nilüfer Akkılıç Kütüphanesi, 3. Baskı, Bursa 2009.

Arseven, Celal Esat, Seyyar Sergi ile Seyahat Intibalan, Kitabevi, İstanbul 2008.

Gürsu, Süreyya, 1926 Senesinde Mapılan Seyyar Sergi Seferi Hatıralar, (Derleyen: Refik Akdoğan), İstanbul 2006.

Nezihi, Hakkı, 50 Tillı Oda Hayat, T.C İstanbul Ticaret ve Sanayi Odası Neşriyatı, İstanbul 1932.

Ökçün, A. Gündüz, Türkiye İktisat Kongresi 1923 İzmir, Haberler-Belgeler-Yorumlar, Ankara Üniversitesi Siyasal Bilgiler Fakültesi Yayınları, Ankara 1971.

Seyyar Sergi Talimat ve Program, Hilal Matbaası, 1926.

Sönmez, Oktay, Anılarda Gemiler Ufkun Ötesinde Kayboldular, Türkiye İş Bankası Kültür Yayınları, İstanbul 2001.

Tutel, Eser, Seyr-i Sefain Öncesi ve Sonrası, İletişim Yayınları, 3. Baskı, İstanbul 2006. , Gemiler, Süvariler, İskeleler, İletişim Yayınları, İstanbul 1998.

Türkiye Işs Bankası Tarihi, (Proje yöneticisi: Uygur Kocabaşoğlu), Türkiye İş Bankası Kültür Yayınları, İstanbul 2001.

Türkiye Sergicilik ve Fuarcılk Tarihi, (Proje Yöneticisi: Gökhan Akçura, Editör: Günel Tüzün), Tarih Vakfi, İstanbul 2009. 


\section{MAKALELER}

Akkılıç, Yılmaz, "Seyyar Sergi”, Bursa Defteri, Sayı 24, Aralık 2004, s. 113-116.

Ergüney, Yeşim Duygu - Pilehvarian, Nuran Kara, "Ondokuzuncu Yüzyıl Dünya Fuarlarında Osmanlı Temsiliyeti”, Megaron, Cilt 10, Sayı 2, 2015, s. 224-240.

Germaner, Semra, “Osmanlı İmparatorluğu'nun Uluslararası Sergilere Katılımı ve Kültürel Sonuçları", Tarih ve Toplum, Gilt 16, Sayı 95, s. 289-296.

Önsoy, Rifat, "Osmanlı İmparatorluğu'nun Katıldığı İlk Uluslararası Sergiler ve Sergi-i Umumi-i Osmani (1863 İstanbul Sergisi), Belleten, Cilt 48, Sayı 185, Ocak 1983, s. 195-235.

Tutel, Eser, "Gülcemal'in Süvarisi Lütfi Kaptan”, Tarih ve Toplum, Mart 1996, Cilt 25, Sayı 147, s. 149-156.

\section{TV PROGRAMI/BELGESELI}

"Karadeniz: Seyr-i Türkiye”, NTV, 21 Nisan 2006.

\section{SÜRELI YAYINLAR}

Akbaba

Akşam

Bursa Defteri

Cumhuriyet

Habertürk

Hakimiyet-i Milliye

İstanbul Ticaret ve Sanayi Odası Mecmuası (ITSOM)

Meslek

Milliyet

Resimli Gazete

Skylife

Şehremaneti Mecmuast

Tarih ve Toplum

Vakit 


\section{EKLER}

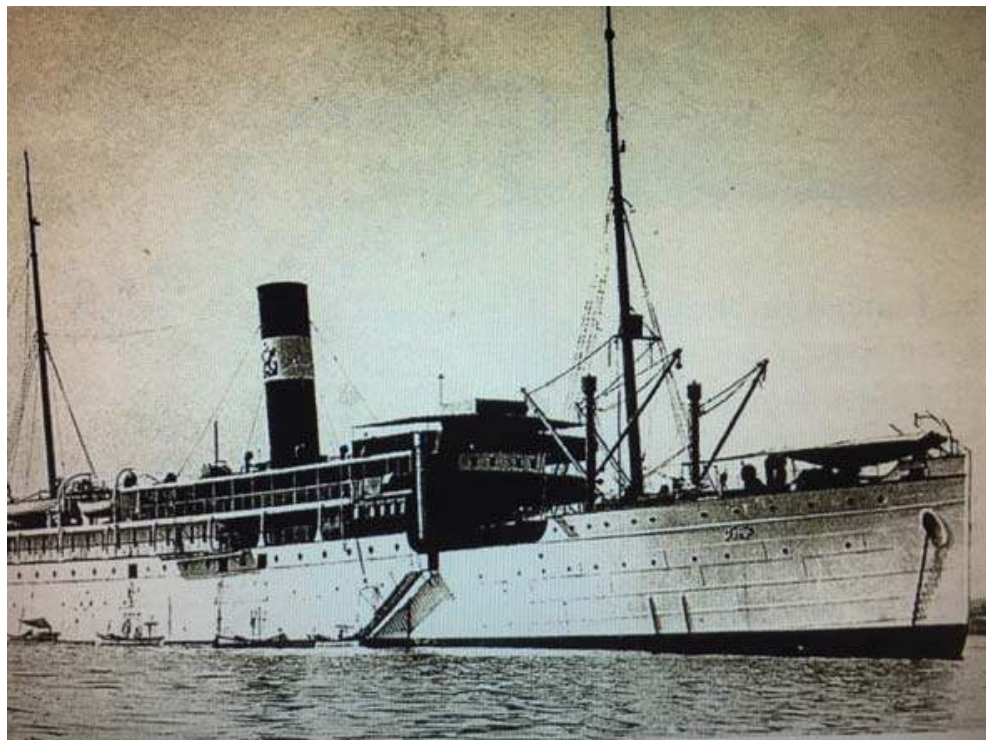

Ek 1: Seyyar Sergi’ye ev sahipliği yapan Karadeniz Vapuru.

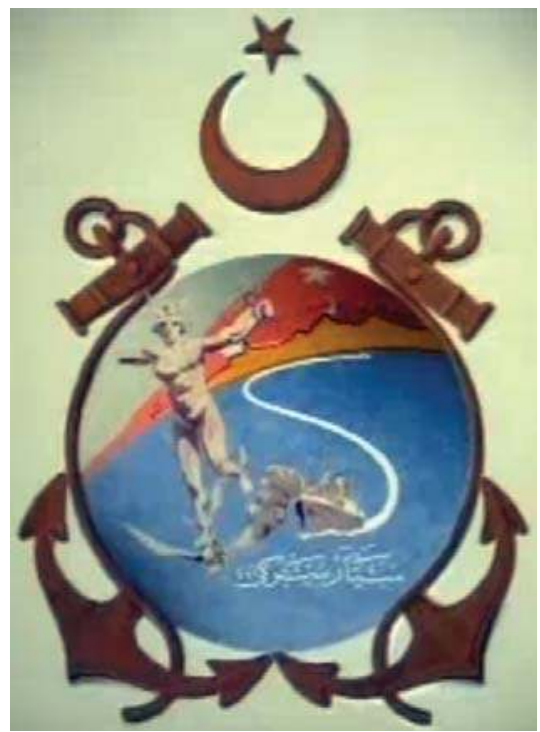

Ek 2: Seyyar Sergi'nin Logosu. 


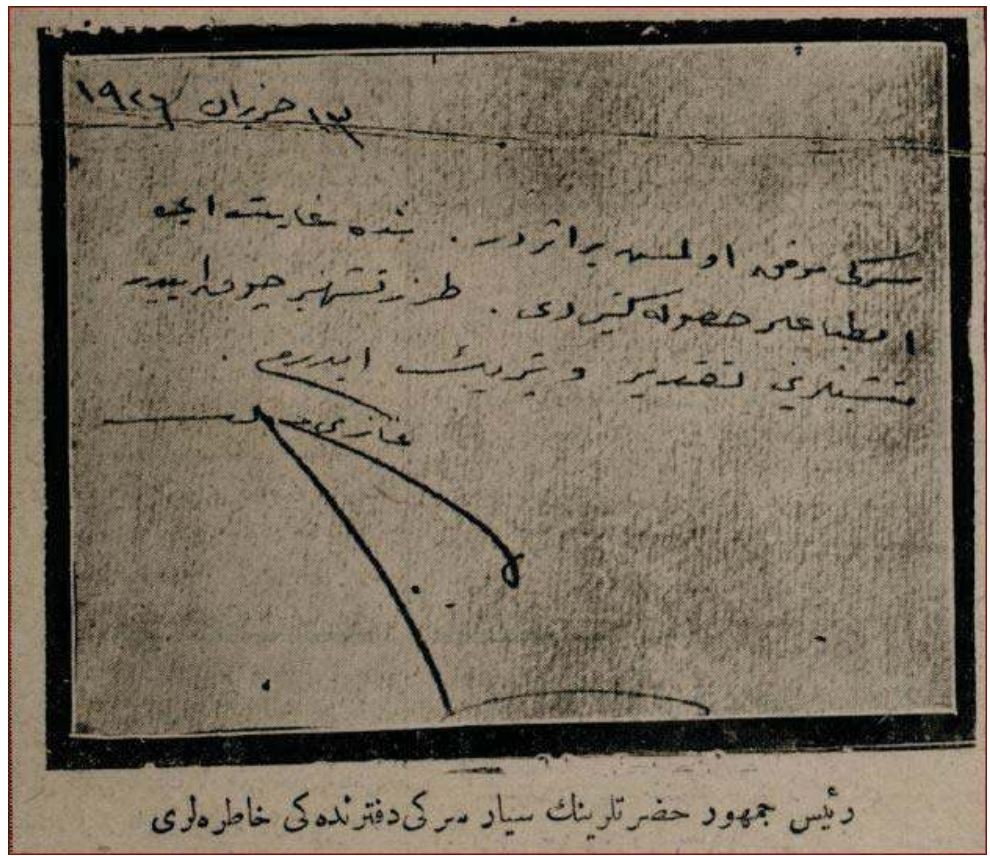

Ek 3: Mustafa Kemal Paşa'nın Seyyar Sergi defterine yazdığı imzalı yazı. (Cumhuriyet, 15 Haziran 1926).

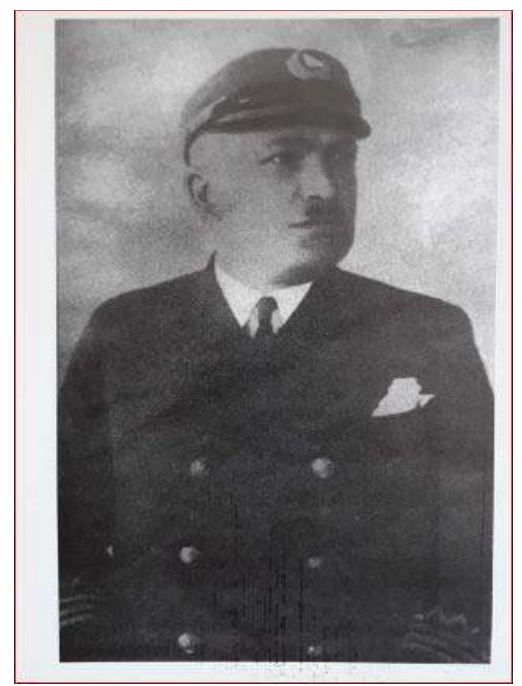

Ek 4: Seyyar Sergi gemisi Karadeniz Vapuru'nun kaptanı Lütfi Kaptan. 


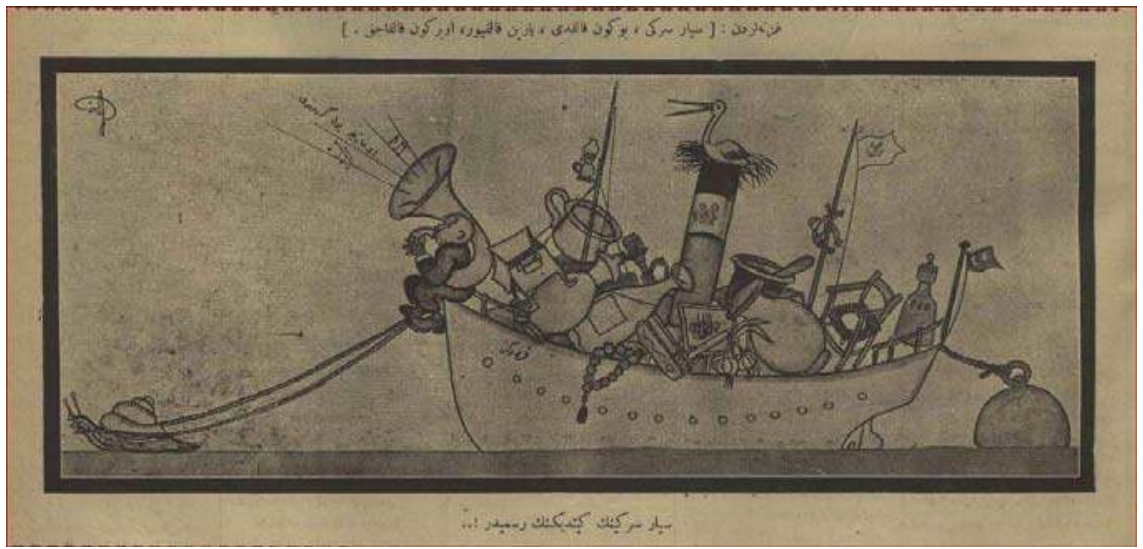

Ek 5: Seyyar Sergi'nin sürekli ertelenen hareket zamanını hicveden mizah dergisi Akbaba'nın karikatürü (Akbaba, 10 Haziran 1926)

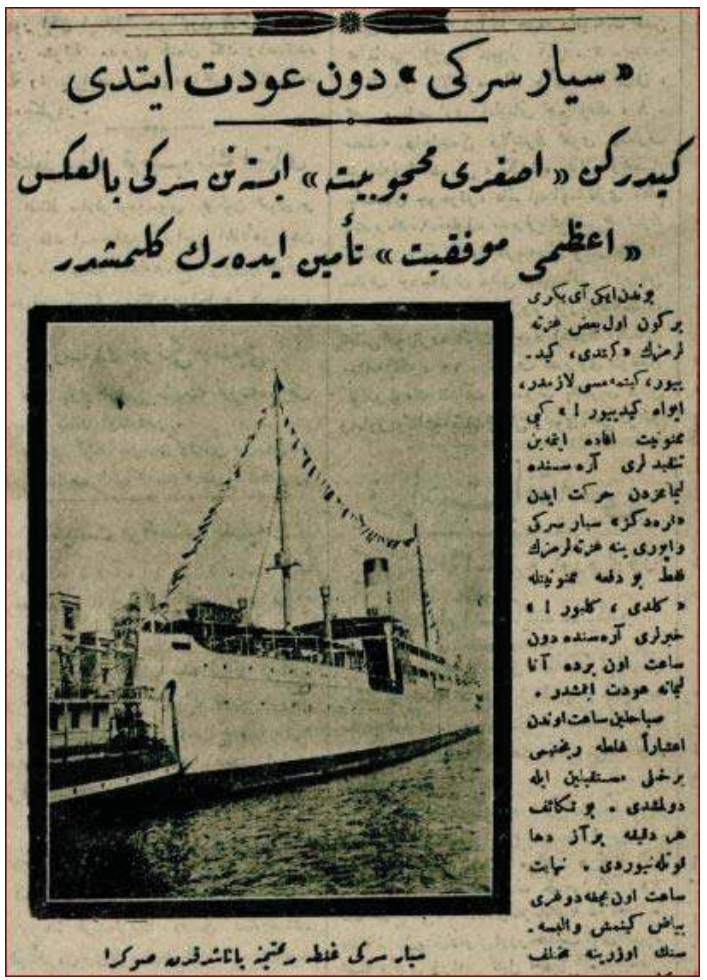

Ek 6: Seyyar Sergi'nin İstanbul'a dönüşünü yazan bir gazete haberi. (Milliyet, 6 Eylül 1926). 